\title{
Enhanced Component Performance Study: Motor-Operated Valves 1998-2012
}

\author{
T. E. Wierman
}

October 2013

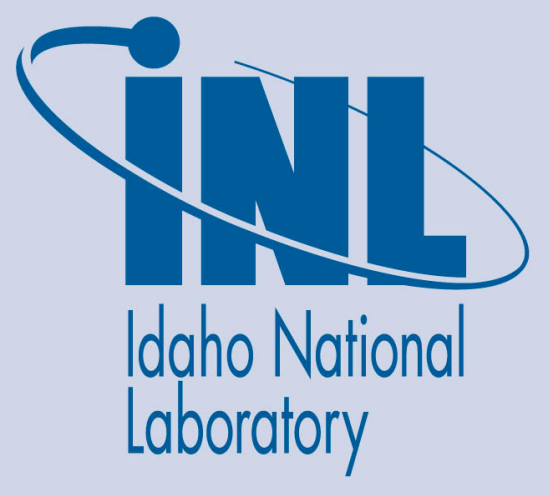

The INL is a U.S. Department of Energy National Laboratory operated by Battelle Energy Alliance 
INL/EXT-14-31121

\section{Enhanced Component Performance Study: Motor-Operated Valves 1998-2012}

T. E. Wierman

October 2013

Update Completed September 2013

Idaho National Laboratory

Risk Assessment and Management Services Department Idaho Falls, Idaho 83415

\section{http://www.inl.gov}

Prepared for the Division of Risk Assessment Office of Nuclear Regulatory Research U.S. Nuclear Regulatory Commission Washington, D.C. 20555 Job Code N6631 
NOTICE

This information was prepared as an account of work sponsored by an agency of the U.S. Government. Neither the U.S. Government nor any agency thereof, nor any of their employees, makes any warranty, express or implied, or assumes any legal liability or responsibility for any third party's use, or the results of such use, of any information, apparatus, product, or process disclosed herein, or represents that its use by such third party would not infringe privately owned rights. The views expressed herein are not necessarily those of the U.S. Nuclear Regulatory Commission. 



\begin{abstract}
This report presents an enhanced performance evaluation of motor-operated valves (MOVs) at U.S. commercial nuclear power plants. The data used in this study are based on the operating experience failure reports from fiscal year 1998 through 2012 for the component reliability as reported in the Equipment Performance and Information Exchange (EPIX). The MOV failure modes considered are failure to open/close, failure to operate or control, and spurious operation. The component reliability estimates and the reliability data are trended for the most recent 10-year period while yearly estimates for reliability are provided for the entire active period. No statistically significant increasing trends were identified in the MOV results. Statistically significant decreasing trends were identified for failure to open/close and operation demands.
\end{abstract}




\section{CONTENTS}

ABSTRACT iii

ACRONYMS ix

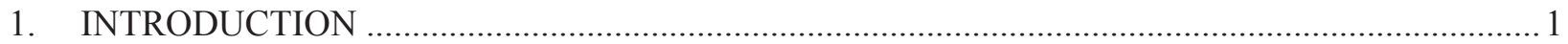

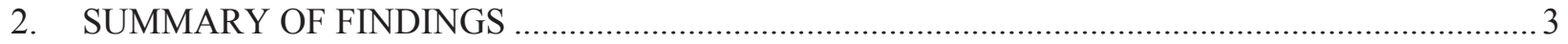

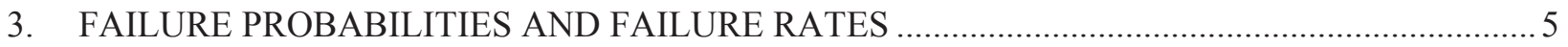

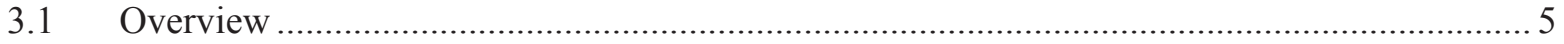

3.2 MOV Failure Probability and Failure Rate Trends ............................................................ 6

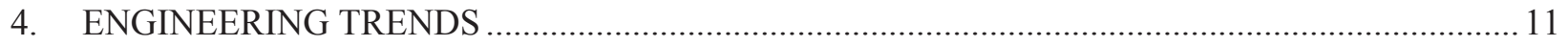

4.1 MOV Engineering Analysis by Failure Modes ................................................................. 20

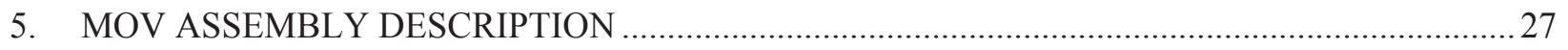

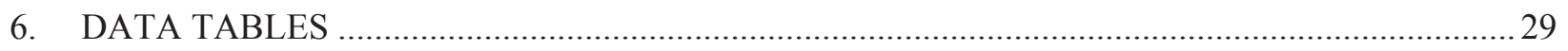

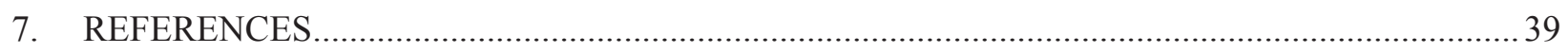

FIGURES

1. Failure probability estimate trend for MOV FTOC, all systems, industry-wide trend of MOVs

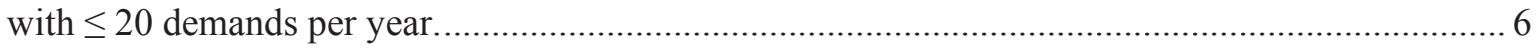

2. Failure probability estimate trend for MOV FTOC, all systems, industry-wide trend of MOVs

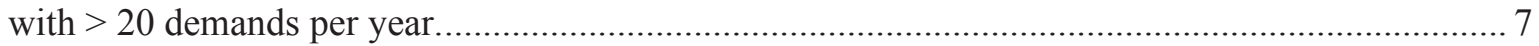

3. Failure rate estimate trend for MOV FTOP, all systems, industry-wide trend of MOVs with $\leq$ 20 demands per year.

4. Failure rate estimate trend for MOV FTOP, all systems, industry-wide trend of MOVs with > 20 demands per year.

5. Failure rate estimate trend for MOV SO, all systems, industry-wide trend of MOVs with $\leq 20$ demands per year.

6. Failure rate estimate trend for MOV SO, all systems, industry-wide trend of MOVs with $>20$ demands per year.

7. Frequency (demands per reactor year) of MOV operation demands, $\leq 20$ demands per year. 
8. Frequency (demands per reactor year) of MOV operation demands, $>20$ demands per year.

9. Frequency (failures per reactor year) of MOV FTOC events $\leq 20$ demands per year......................... 13

10. Frequency (failures per reactor year) of MOV FTOC events $>20$ demands per year....................... 13

11. Frequency (failures per reactor year) of MOV FTOP events $\leq 20$ demands per year. ...................... 14

12. Frequency (failures per reactor year) of MOV FTOP events $>20$ demands per year. ...................... 14

13. Frequency (failures per reactor year) of MOV SO events $\leq 20$ demands per year........................... 15

14. Frequency (failures per reactor year) of MOV SO events $>20$ demands per year........................... 15

15. MOV failure breakdown by period, sub component, and failure mode.......................................... 22

16. MOV breakdown by time period, cause group, and failure mode. ................................................. 23

17. MOV component failure distribution by period, failure mode, and method of detection................... 24

18. MOV component failure distribution by period, failure mode, and recovery................................. 25

\section{TABLES}

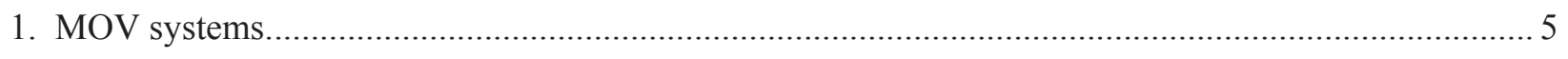

2. Industry-wide distributions of $\mathrm{p}$ (failure probability) and $\lambda$ (hourly rate) for TDPs............................. 5

3. Summary of TDP failure counts for the FTS failure mode over time by system. ............................. 16

4. Summary of MOV failure counts for the FTOP failure mode over time by system $\leq 20$

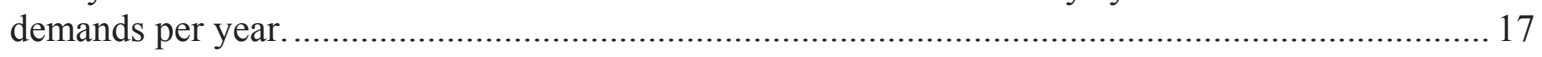

5. Summary of MOV failure counts for the SO failure mode over time by system $\leq 20$ demands

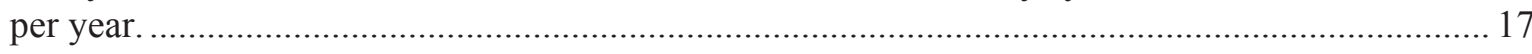

6. Summary of MOV failure counts for the FTOC failure mode over time by system $>20$

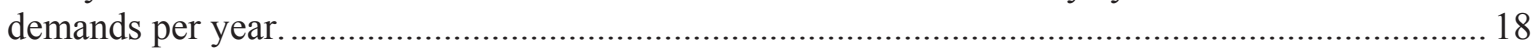

7. Summary of MOV failure counts for the FTOP failure mode over time by system $>20$

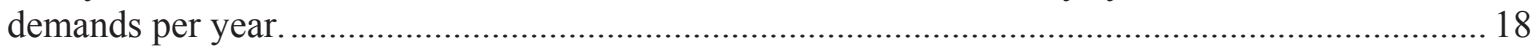

8. Summary of MOV failure counts for the SO failure mode over time by system $>20$ demands per year.

9. Component failure cause groups.

10. Plot data for industry-wide MOV FTOC trend with $\leq 20$ demands per year. Figure 1 ....................29

11. Plot data for industry-wide MOV FTOC trend with $>20$ demands per year. Figure 2 .................... 30 
12. Plot data for industry-wide MOV FTOP trend with $\leq 20$ demands per year. Figure 3

13. Plot data for industry-wide MOV FTOP trend with $>20$ demands per year. Figure $4 \ldots \ldots \ldots \ldots \ldots \ldots \ldots . . . . . . . . .32$

14. Plot data for industry-wide MOV SO trend with $\leq 20$ demands per year. Figure 5 ......................... 32

15. Plot data for industry-wide MOV SO trend, $>20$ demands per year. Figure 6 ................................ 33

16. Plot data for frequency (events per reactor year) of MOV operation demands with $\leq 20$

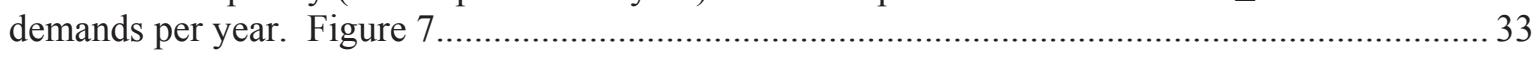

17. Plot data for frequency (events per reactor year) of MOV operation demands with $>20$

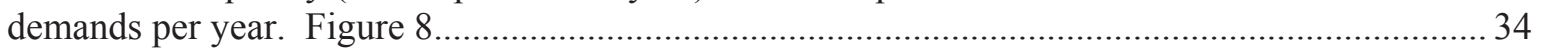

18. Plot data for frequency (events per reactor year) of MOV FTOC events with $\leq 20$ demands

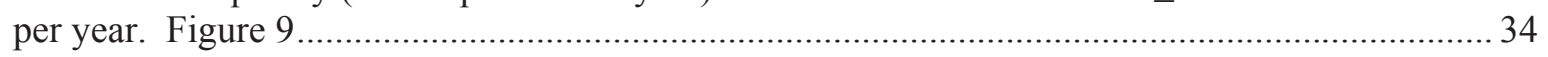

19. Plot data for frequency (events per reactor year) of MOV FTOC events with $>20$ demands

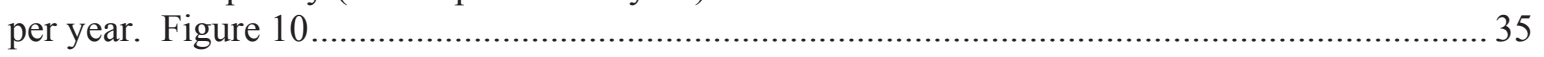

20. Plot data for frequency (events per reactor year) of MOV FTOP events with $\leq 20$ demands

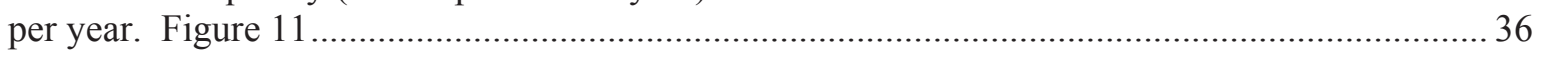

21. Plot data for frequency (events per reactor year) of MOV FTOP events with $>20$ demands

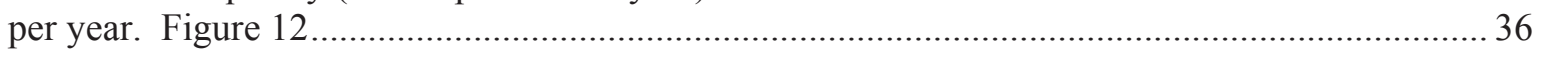

22. Plot data for frequency (events per reactor year) of MOV SO events $\leq 20$ demands per year.

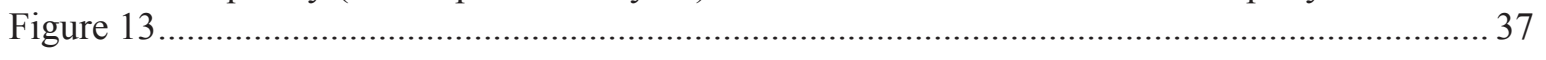

23. Plot data for frequency (events per reactor year) of MOV SO events $>20$ demands per year. Figure 14 


\section{ACRONYMS}

\begin{tabular}{|c|c|}
\hline AFW & Auxiliary feedwater \\
\hline $\begin{array}{l}\text { CCW } \\
\text { CNID } \\
\text { CRD } \\
\text { CSR } \\
\text { CVC }\end{array}$ & $\begin{array}{l}\text { component cooling water } \\
\text { constrained noninformative prior distribution } \\
\text { control rod drive } \\
\text { containment spray recirculation } \\
\text { chemical and volume control }\end{array}$ \\
\hline $\begin{array}{l}\text { EPIX } \\
\text { EPS }\end{array}$ & $\begin{array}{l}\text { Equipment Performance and Information Exchange } \\
\text { emergency power supply }\end{array}$ \\
\hline $\begin{array}{l}\text { FTOC } \\
\text { FTOP } \\
\text { FY }\end{array}$ & $\begin{array}{l}\text { failure-to-open/close (failure to operate) } \\
\text { failure to operate or control } \\
\text { fiscal year }\end{array}$ \\
\hline $\begin{array}{l}\mathrm{HCI} \\
\mathrm{HCS} \\
\mathrm{HPI}\end{array}$ & $\begin{array}{l}\text { high-pressure coolant injection } \\
\text { high-pressure core spray } \\
\text { high-pressure injection }\end{array}$ \\
\hline ISO & isolation condenser \\
\hline LCS & low-pressure core spray \\
\hline $\begin{array}{l}\text { MOV } \\
\text { MSPI }\end{array}$ & $\begin{array}{l}\text { motor-operated valve } \\
\text { Mitigating Systems Performance Index }\end{array}$ \\
\hline PRA & probabilistic risk assessment \\
\hline $\begin{array}{l}\text { RCI } \\
\text { RCS } \\
\text { RHR }\end{array}$ & $\begin{array}{l}\text { reactor core isolation } \\
\text { reactor coolant } \\
\text { residual heat removal }\end{array}$ \\
\hline $\begin{array}{l}\text { SO } \\
\text { SWN } \\
\text { SWS }\end{array}$ & $\begin{array}{l}\text { spurious operation } \\
\text { normally running service water } \\
\text { standby service water }\end{array}$ \\
\hline TDP & turbine-driven pump \\
\hline UA & unavailability \\
\hline ISS & vapor suppression \\
\hline
\end{tabular}




\section{Enhanced Component Performance Study: Motor-Operated Valves 1998-2012}

\section{INTRODUCTION}

This report presents an enhanced performance evaluation of motor-operated valves (MOVs) at U.S. commercial nuclear power plants. This report does not estimate values for use in probabilistic risk assessments (PRAs), but does evaluate component performance over time. The 2010 Component Reliability Update (Reference 1), which is an update to Reference 2 (NUREG/CR-6928), reports the MOV unreliability estimates using Equipment Performance and Information Exchange (EPIX) data from 1998 through 2010 for use in PRAs.

The data used in this study are based on the operating experience failure reports from fiscal year (FY)-98 through FY-12 for the component reliability as reported in EPIX. The MOV failure modes considered are failure-to-open/close (failure to operate) (FTOC), (failure to operate or control) (FTOP) and spurious operation (SO). The component reliability estimates and the reliability data are trended for the most recent 10 -year period while yearly estimates for reliability are provided for the entire active period.

Previously, the study relied on operating experience obtained from licensee event reports, Nuclear Plant Reliability Data System, and EPIX. The EPIX database (which includes as a subset the Mitigating Systems Performance Index (MSPI) designated devices) has matured to the point where component availability and reliability can be estimated with a higher degree of assurance of accuracy. In addition, the population of data is much larger than the population used in the previous study.

The objective of the effort for the updated component performance studies is to obtain annual performance trends of failure rates and probabilities. An overview of the trending methods, glossary of terms, and abbreviations can be found in the Overview and Reference document on the Reactor Operational Experience Results and Databases web page.

The objective of the enhanced component performance study is to present an analysis of factors that could influence the system and component trends in addition to annual performance trends of failure rates and probabilities. Engineering analyses were performed with respect to time period and failure mode (Section 4.1). The factors analyzed are sub-component, failure cause, detection method, and recovery. 


\section{SUMMARY OF FINDINGS}

The results of this study are summarized in this section. Of particular interest is the existence of any statistically significant ${ }^{\mathrm{a}}$ increasing trends. In this update, no statistically significant increasing trends were identified in the MOV results. Statistically significant decreasing trends were identified in the MOV results for the following:

- Failure probability estimate trend for MOV FTOC, all systems, industry-wide trend of MOVs with $>20$ demands/yr (see Figure 2)

- Frequency (failures per reactor year) of MOV FTOC events $>20$ demands/yr (see Figure 10) and highly statistically significant decreasing trends were identified in the MOV results for

- Frequency (demands per reactor year) of MOV operation demands, $\leq 20$ demands/yr. (see Figure 7)

Considering the low-demand MOVs; Table 3 shows that $91 \%$ of the MOV FTOC failures occurred in eight systems. Table 4 shows that $88 \%$ of the MOV FTOP failures occurred in five systems. Similarly, Table 5 shows that $94 \%$ of the MOV SO failures occurred in seven systems.

Considering the high-demand MOVs; Table 6 shows that $84 \%$ of the MOV FTOC failures occurred in five systems. Table 7 shows that $90 \%$ of the MOV FTOP failures occurred in six systems. Similarly, Table 8 shows that all of the MOV SO failures occurred (or were identified) in three systems.

a. Statistical significance is defined in terms of the 'p-value.' A p-value is a probability indicating whether to accept or reject the null hypothesis that there is no trend in the data. P-values of less than or equal to 0.05 indicate that we are $95 \%$ confident that there is a trend in the data (reject the null hypothesis of no trend.) By convention, we use the "Michelin Guide" scale: p-value $<0.05$ (statistically significant), p-value $<0.01$ (highly statistically significant); p-value $<0.001$ (extremely statistically significant). 


\section{FAILURE PROBABILITIES AND FAILURE RATES}

\subsection{Overview}

Trends of industry-wide failure probabilities and failure rates of MOVs have been calculated from the operating experience for the FTOC and SO failure modes. The MOV data set obtained from EPIX was segregated to MOVs with $\leq 20$ demands/year and MOVs with $>20$ demands/yr and includes MOVs in the systems listed in Table 1. NUREG/CR-6928 lists the industry failure data for MOVs with $\leq$ 20 demands/yr. Table 2 shows industry-wide failure probability and failure rate results for the MOV with $\leq 20$ demands/yr from Reference 1. No results are shown for $>20$ demands/yr MOVs because Reference 1 does not present results for $>20$ demands/yr.

The MOVs are assumed to operate both when the reactor is critical and during shutdown periods. The number of valves in operation is assumed to be constant throughout the study period. All demand types are considered - testing, non-testing, and, as applicable, engineered safety feature demands.

Table 1. MOV systems.

\begin{tabular}{|c|c|c|c|c|}
\hline \multirow[b]{2}{*}{ System } & \multirow[b]{2}{*}{ Description } & \multicolumn{3}{|c|}{ MOV Component Count } \\
\hline & & Total & $\leq 20$ demands/yr & $>20$ demands/yr \\
\hline AFW & Auxiliary feedwater & 581 & 445 & 136 \\
\hline CCW & Component cooling water & 834 & 674 & 160 \\
\hline CRD & Control rod drive & 25 & 10 & 15 \\
\hline CSR & Containment spray recirculation & 345 & 324 & 21 \\
\hline CVC & Chemical and volume control & 21 & 21 & \\
\hline $\mathrm{HCl}$ & High-pressure coolant injection & 269 & 246 & 23 \\
\hline $\mathrm{HCS}$ & High-pressure core spray & 47 & 28 & 19 \\
\hline HPI & High-pressure injection & 1077 & 962 & 115 \\
\hline ISO & Isolation condenser & 20 & 14 & 6 \\
\hline LCS & Low-pressure core spray & 234 & 205 & 29 \\
\hline $\mathrm{RCl}$ & Reactor core isolation & 335 & 303 & 32 \\
\hline RCS & Reactor coolant & 108 & 101 & 7 \\
\hline RHR & Residual heat removal & 2102 & 1803 & 299 \\
\hline SWN & Normally running service water & 952 & 682 & 270 \\
\hline SWS & Standby service water & 284 & 193 & 91 \\
\hline \multirow[t]{2}{*}{ VSS } & Vapor suppression & 14 & 14 & \\
\hline & Total & 7248 & 6025 & 1223 \\
\hline
\end{tabular}

Table 2. Industry-wide distributions of $\mathrm{p}$ (failure probability) and $\lambda$ (hourly rate) for TDPs.

\begin{tabular}{lcccccccc}
\hline \multirow{2}{*}{$\begin{array}{c}\text { Failure } \\
\text { Mode }\end{array}$} & $\mathbf{5 \%}$ & & & & & \multicolumn{3}{c}{ Distribution } \\
\cline { 7 - 9 } & FTOC & $1.76 \mathrm{E}-04$ & $8.12 \mathrm{E}-04$ & $9.63 \mathrm{E}-04$ & $2.27 \mathrm{E}-03$ & Beta & 2.05 & $2.123 \mathrm{E}+03$ \\
\hline FTOP & $7.40 \mathrm{E}-09$ & $5.18 \mathrm{E}-08$ & $6.62 \mathrm{E}-08$ & $1.74 \mathrm{E}-07$ & Gamma & 1.46 & $2.205 \mathrm{E}+07$ \\
\hline SO & $2.54 \mathrm{E}-10$ & $1.72 \mathrm{E}-08$ & $3.39 \mathrm{E}-08$ & $1.24 \mathrm{E}-07$ & Gamma & 0.57 & $1.684 \mathrm{E}+07$ \\
\hline
\end{tabular}




\subsection{MOV Failure Probability and Failure Rate Trends}

Trends in failure probabilities and failure rates are shown in Figures 1-6. The data for the trend plots are contained in Tables $10-15$, respectively.

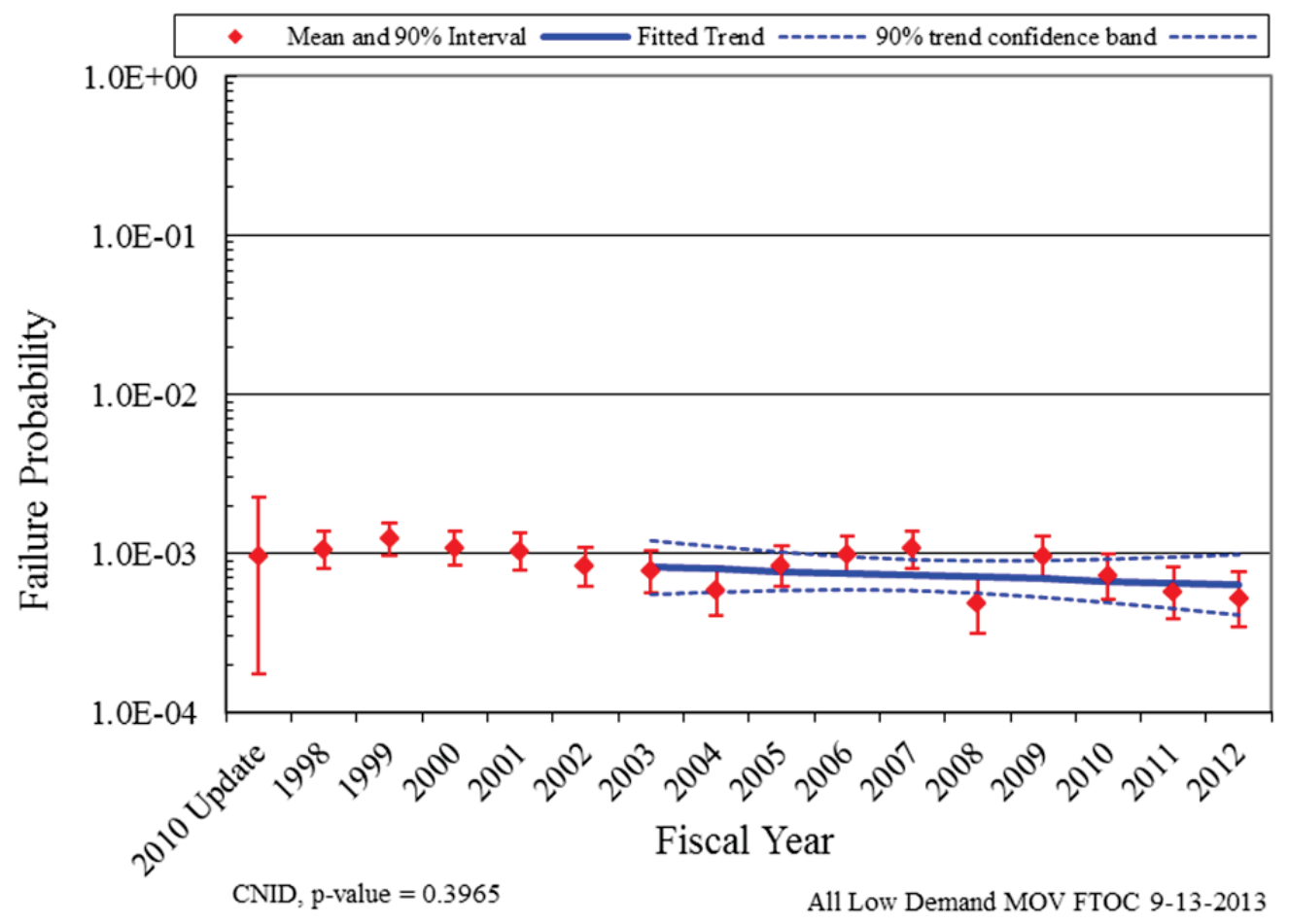

Figure 1. Failure probability estimate trend for MOV FTOC, all systems, industry-wide trend of MOVs with $\leq 20$ demands/yr. 


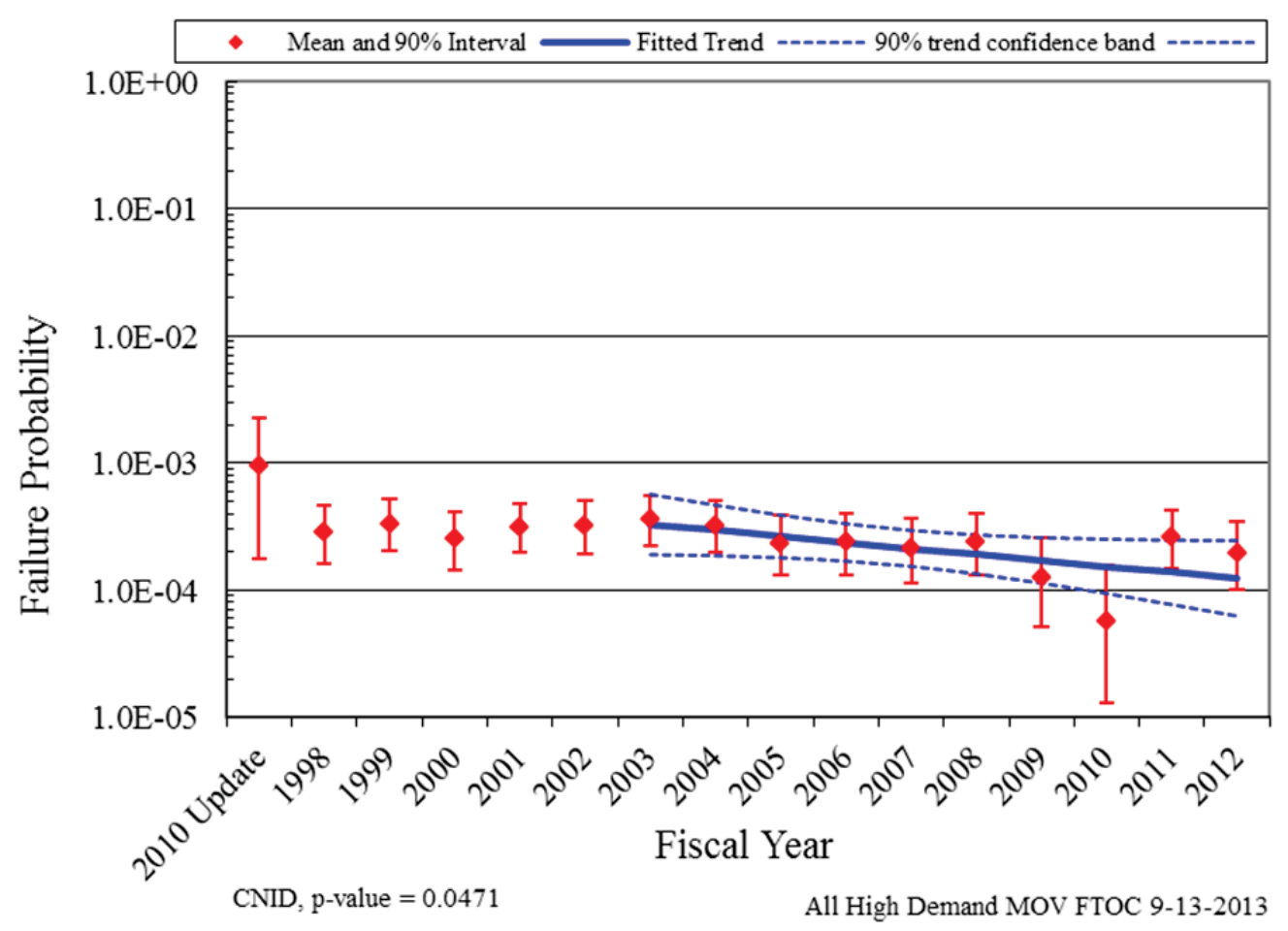

Figure 2. Failure probability estimate trend for MOV FTOC, all systems, industry-wide trend of MOVs with $>20$ demands/yr.

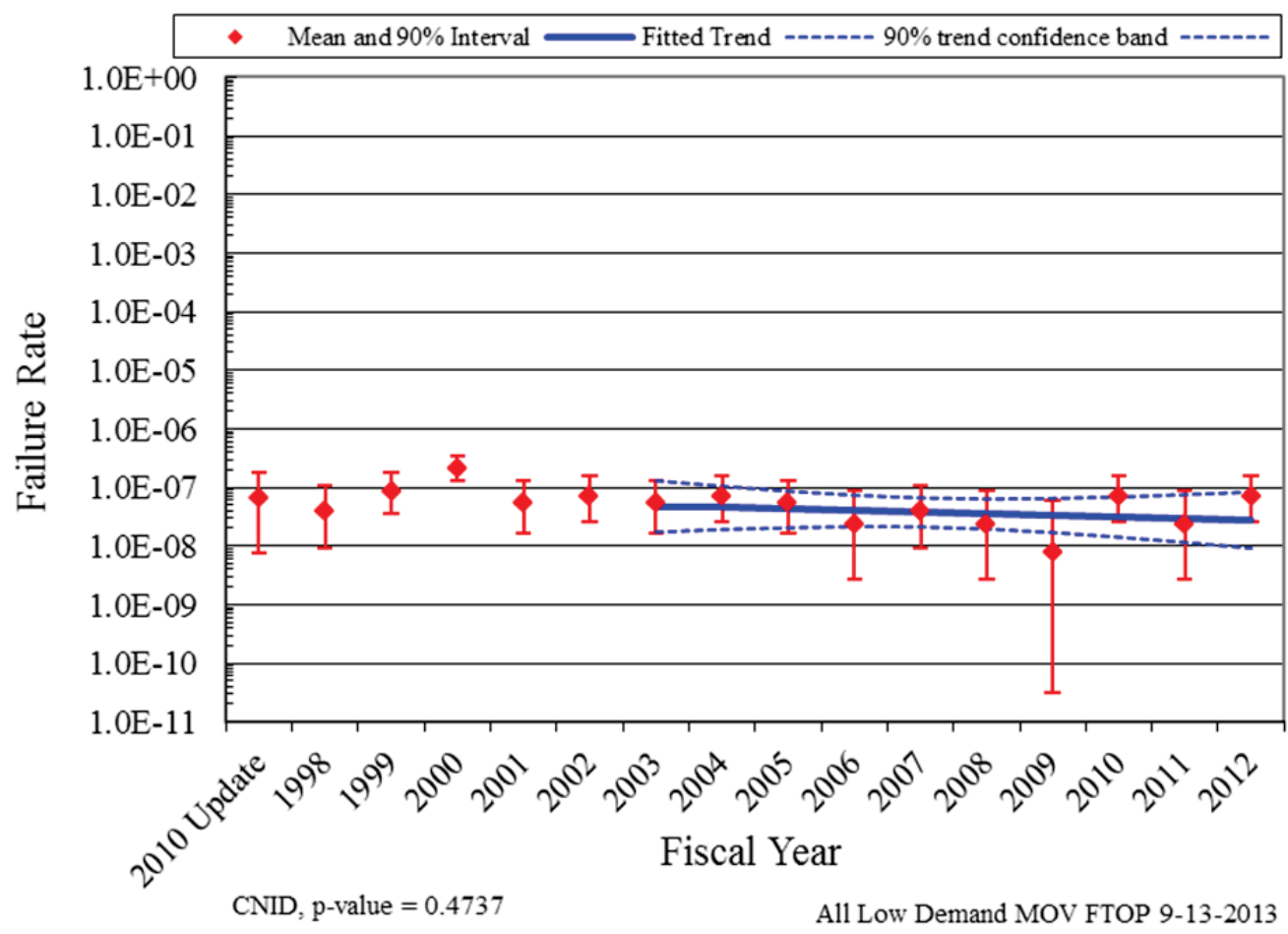

Figure 3. Failure rate estimate trend for MOV FTOP, all systems, industry-wide trend of MOVs with $\leq$ 20 demands/yr. 


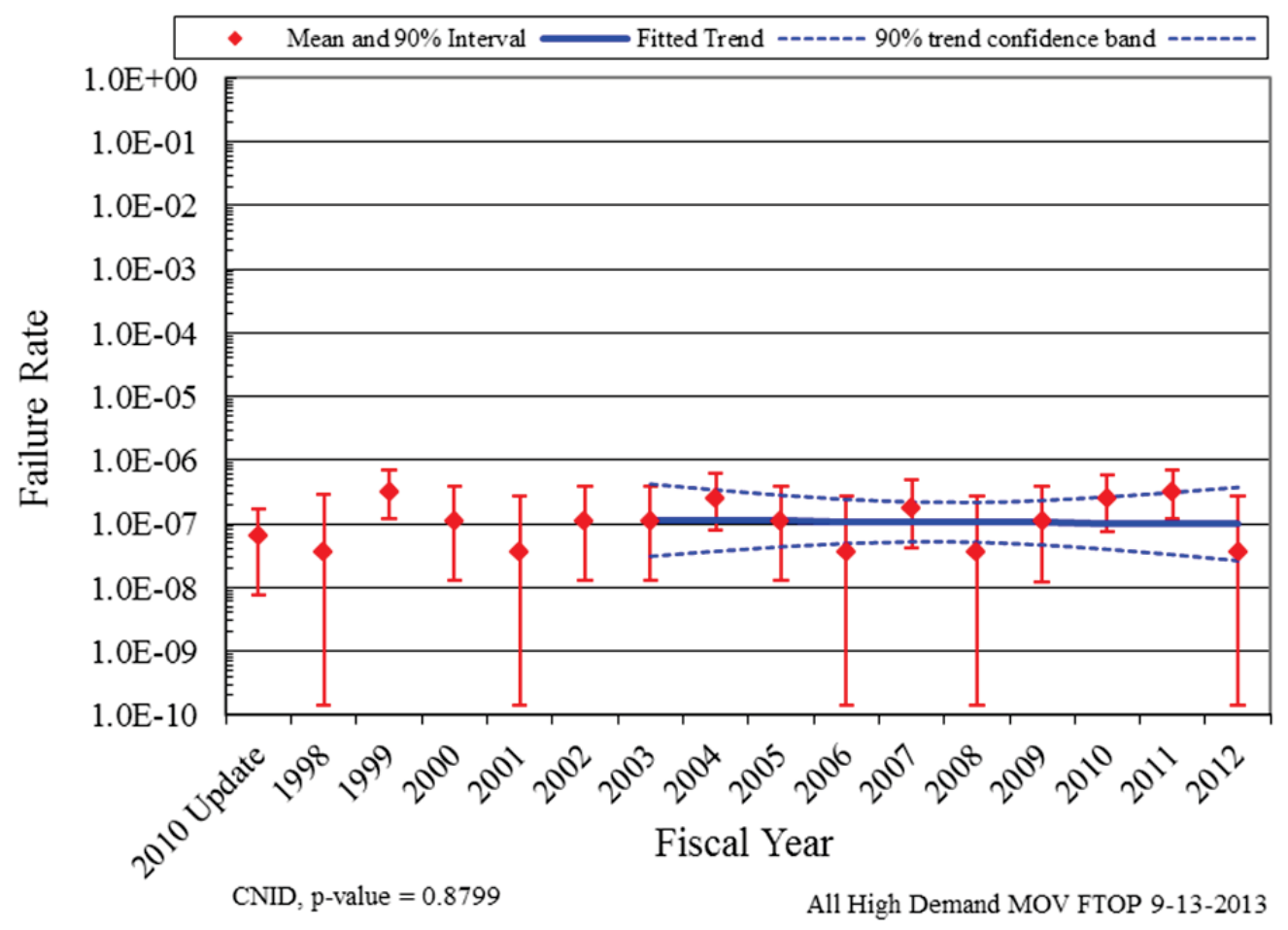

Figure 4. Failure rate estimate trend for MOV FTOP, all systems, industry-wide trend of MOVs with $>20$ demands/yr.

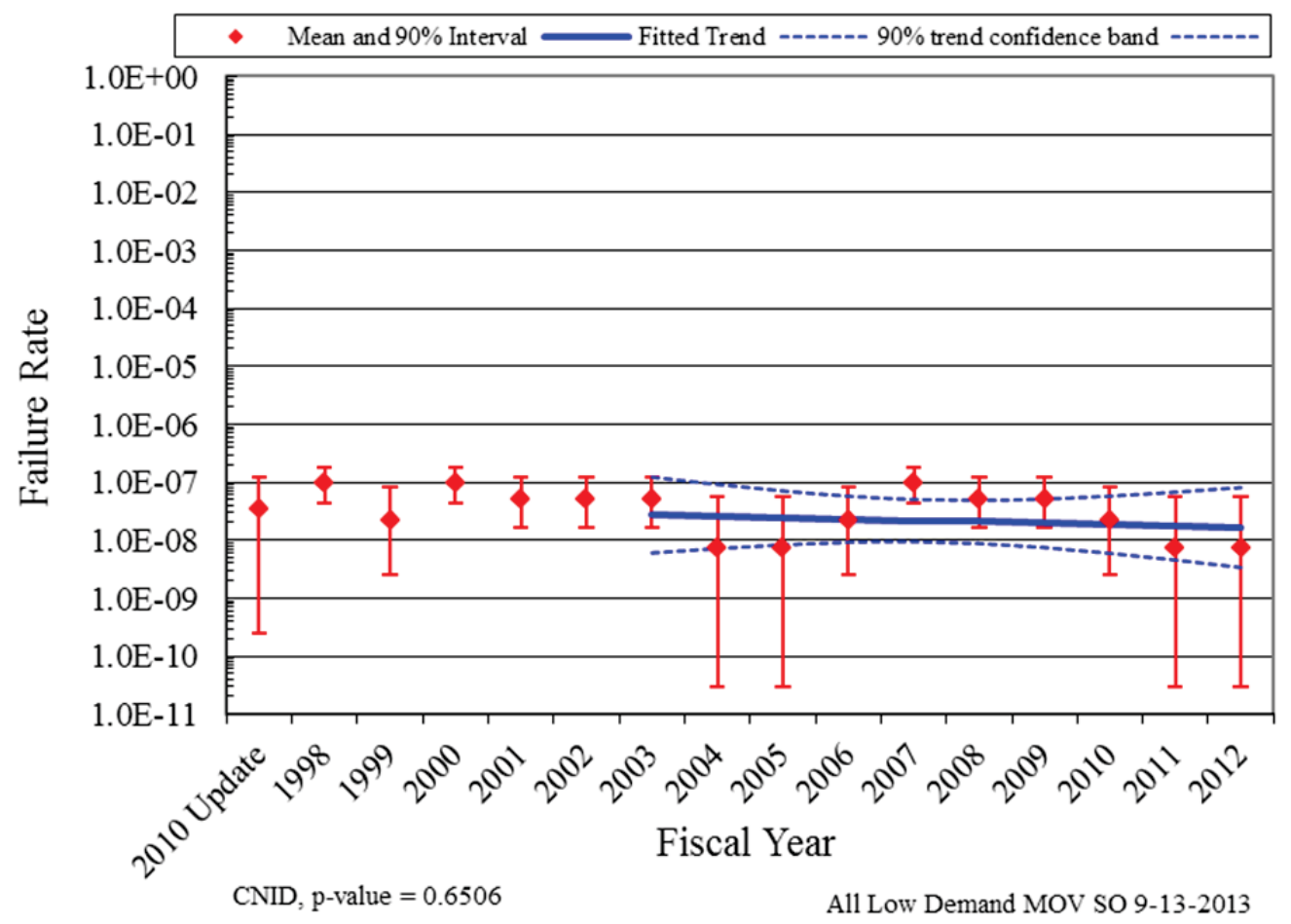

Figure 5. Failure rate estimate trend for MOV SO, all systems, industry-wide trend of MOVs with $\leq$ 20 demands/yr. 


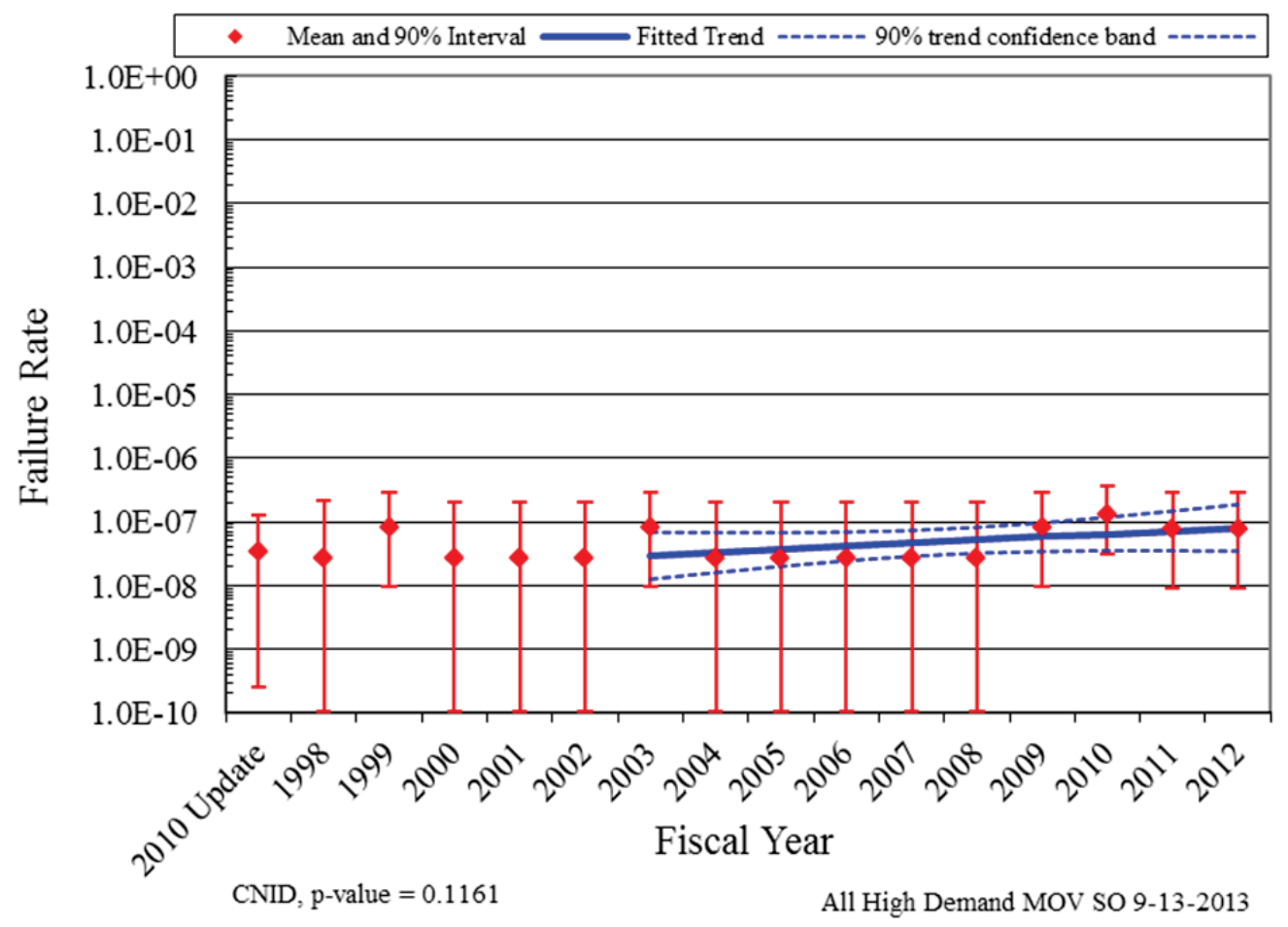

Figure 6. Failure rate estimate trend for MOV SO, all systems, industry-wide trend of MOVs with $>20$ demands/yr.

In the plots, the means of the posterior distributions from the Bayesian update process were trended across the years. The posterior distributions were also used for the vertical bounds for each year. The 5th and 95th percentiles of these distributions give an indication of the relative variation from year to year in the data. When there are no failures, the interval is larger than the interval for years when there are one or more failures. The larger interval reflects the uncertainty that comes from having little information in that year's data. Such uncertainty intervals are determined by the prior distribution. In each plot, a relatively "flat" constrained noninformative prior distribution (CNID) is used, which has large bounds.

The horizontal curves plotted around the regression lines in the graphs form 90 percent simultaneous confidence bands for the fitted lines. The bounds are larger than ordinary confidence intervals for the trended values because they form a band that has a $90 \%$ probability of containing the entire line. In the lower left hand corner of the trend figures, the regression p-values are reported. They come from a statistical test on whether the slope of the regression line might be zero. Low p-values indicate that the slopes are not likely to be zero, and that trends exist. Further information on the trending methods is provided in Section 2 of the Overview and Reference document. A final feature of the trend graphs is that the baseline industry values from Table 2 are shown for comparison. 


\section{ENGINEERING TRENDS}

This section presents frequency trends for MOV failures and demands. The data are normalized by reactor year for plants that have the equipment being trended. Figure 7 shows the trend for total MOV demands of $\leq 20$ demands per reactor-year MOVs. Figure 9 shows the trend in failure events for FTOC mode for MOV $\leq 20$ demands, Figure 11 shows the trend in failure events for FTOP mode for MOV $\leq 20$ demands, and Figure 13 shows the trend for the SO failure events for MOV $\leq 20$ demands.

Figure 8 shows the trend for total MOV demands of $>20$ demands per reactor-year MOVs. Figure 10 shows the trend in failure events for FTOC mode for MOV $>20$ demands, Figure 12 shows the trend in failure events for FTOP mode for MOV > 20 demands, and Figure 14 shows the trend for the SO failure events for MOV > 20 demands.

Table 3 summarizes the failures by system, year, and the FTOC failure mode of MOV $\leq 20$ demands. The systems contributing 50\% or more (in bold) to the FTOC failure mode in Table 3 are AFW, CCW, HCI, HPI, LCS, RCI, RHR, and SWN. Table 4 summarizes the failures by system, year, and the FTOP failure mode of MOV $\leq 20$ demands. The systems contributing $50 \%$ or more (in bold) to the FTOP failure mode in Table 4 are AFW, CCW, HPI, RHR, and SWN. Table 5 summarizes the failures by system, year, and the SO failure mode of MOV $\leq 20$ demands. The systems contributing $50 \%$ or more (in bold) to the SO failure mode in Table 5Error! Reference source not found. are CCW, LCS, RCI, and RHR.

Table 6 summarizes the failures by system, year, and the FTOC failure mode of MOV $>20$ demands. The systems contributing 50\% or more (in bold) to the FTOC failure mode in Table 6 are AFW, CCW, RCI, RHR, SWN, and SWS. Table 7 summarizes the failures by system, year, and the FTOP failure mode of MOV $>20$ demands. The systems contributing $50 \%$ or more (in bold) to the FTOP failure mode in Table 7 are AFW, CCW, LCS, RHR, SWN, and SWS. Table 8 summarizes the failures by system, year, and the SO failure mode of MOV $>20$ demands. The contributing systems in Table 8 for the SO failure mode are RCI, RHR, and SWN.

Tables 16-23provide the frequency (per reactor year) of MOV demands, FTOC events, FTOP events, and SO events, respectively. The systems from Table 2 are trended together for each figure. The rate methods described in Section 2 of the Overview and Reference document are used. 


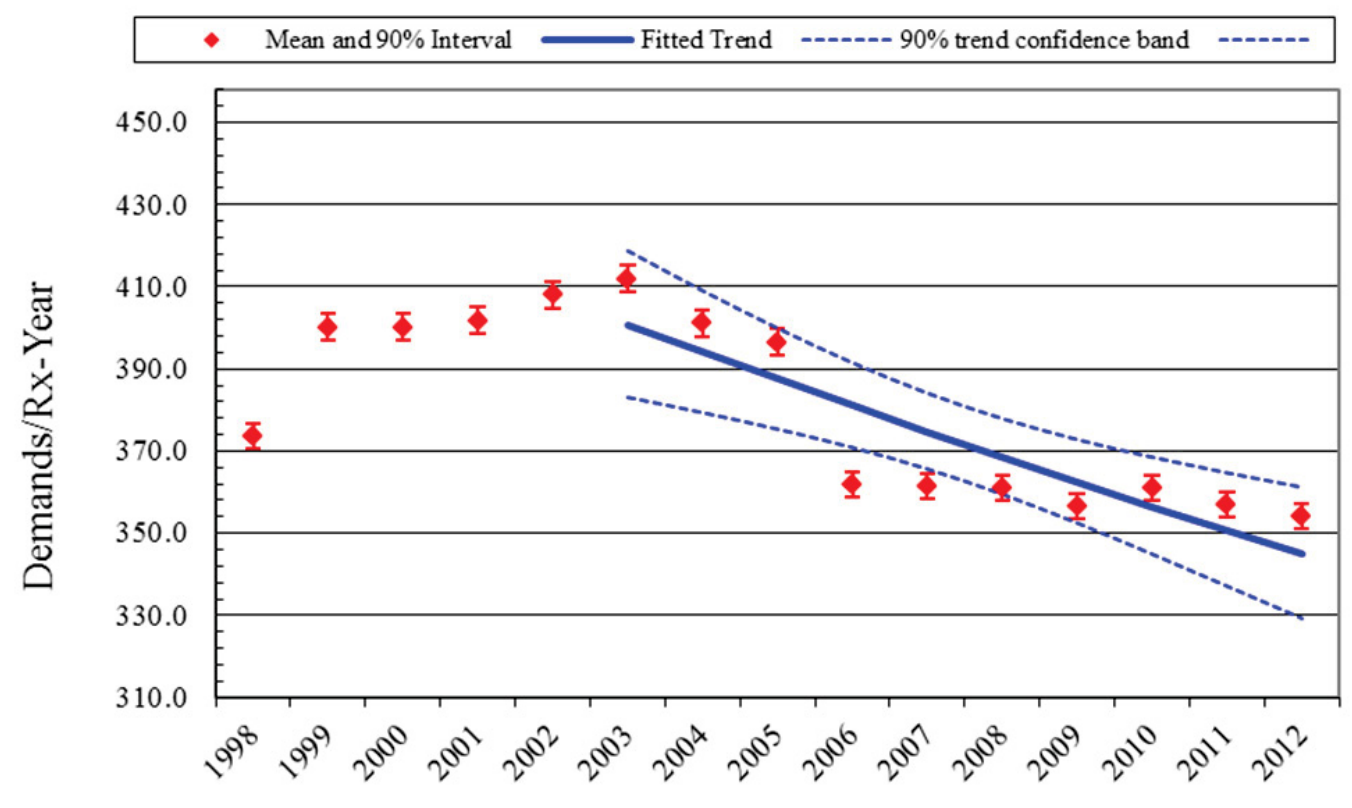

Fiscal Year

CNID, p-value $=0.0012$

All Low Demand MOV FTOC 10-22-2013

Figure 7. Frequency (demands per reactor year) of MOV operation demands, $\leq 20$ demands/yr.

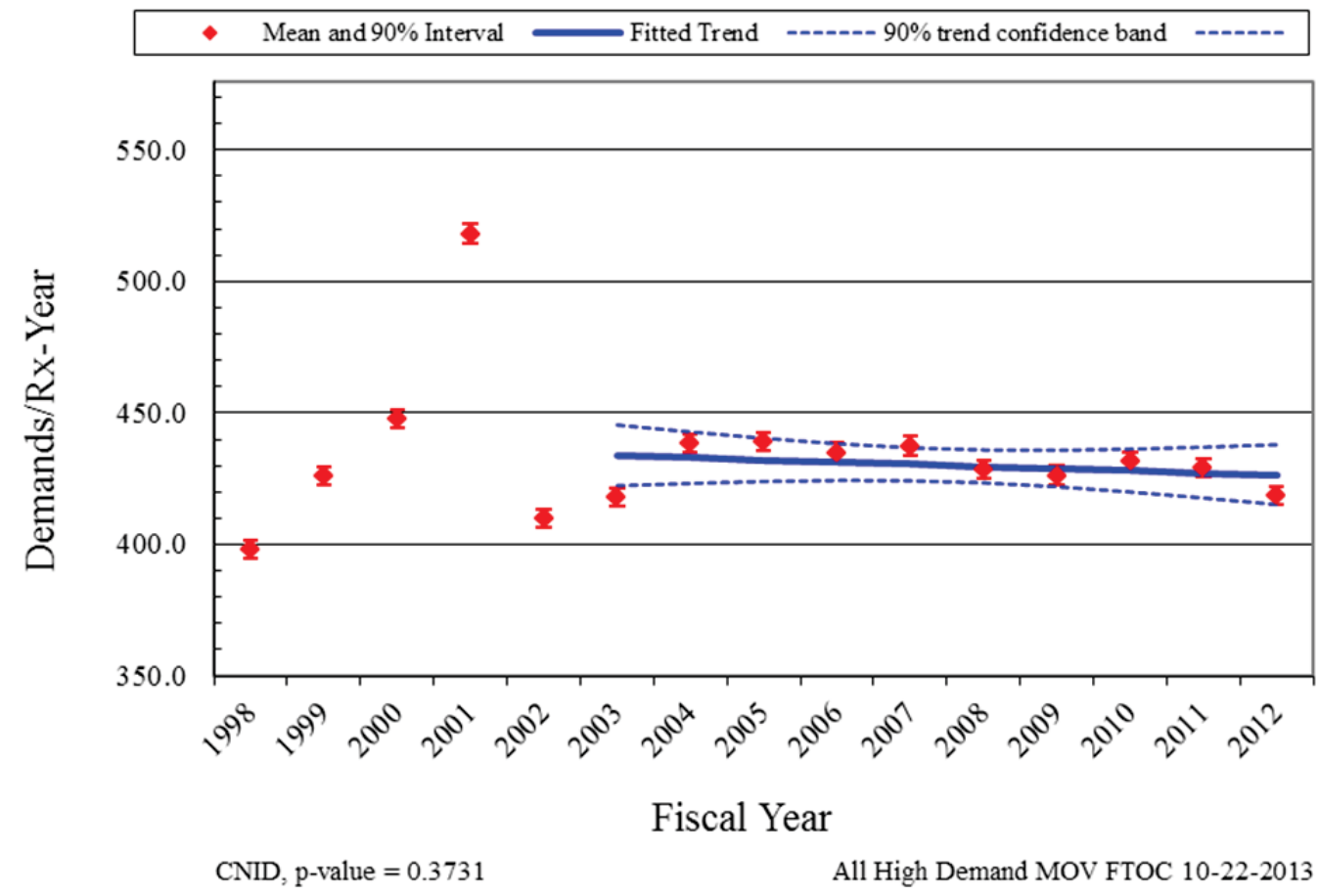

Figure 8. Frequency (demands per reactor year) of MOV operation demands, $>20$ demands/yr. 


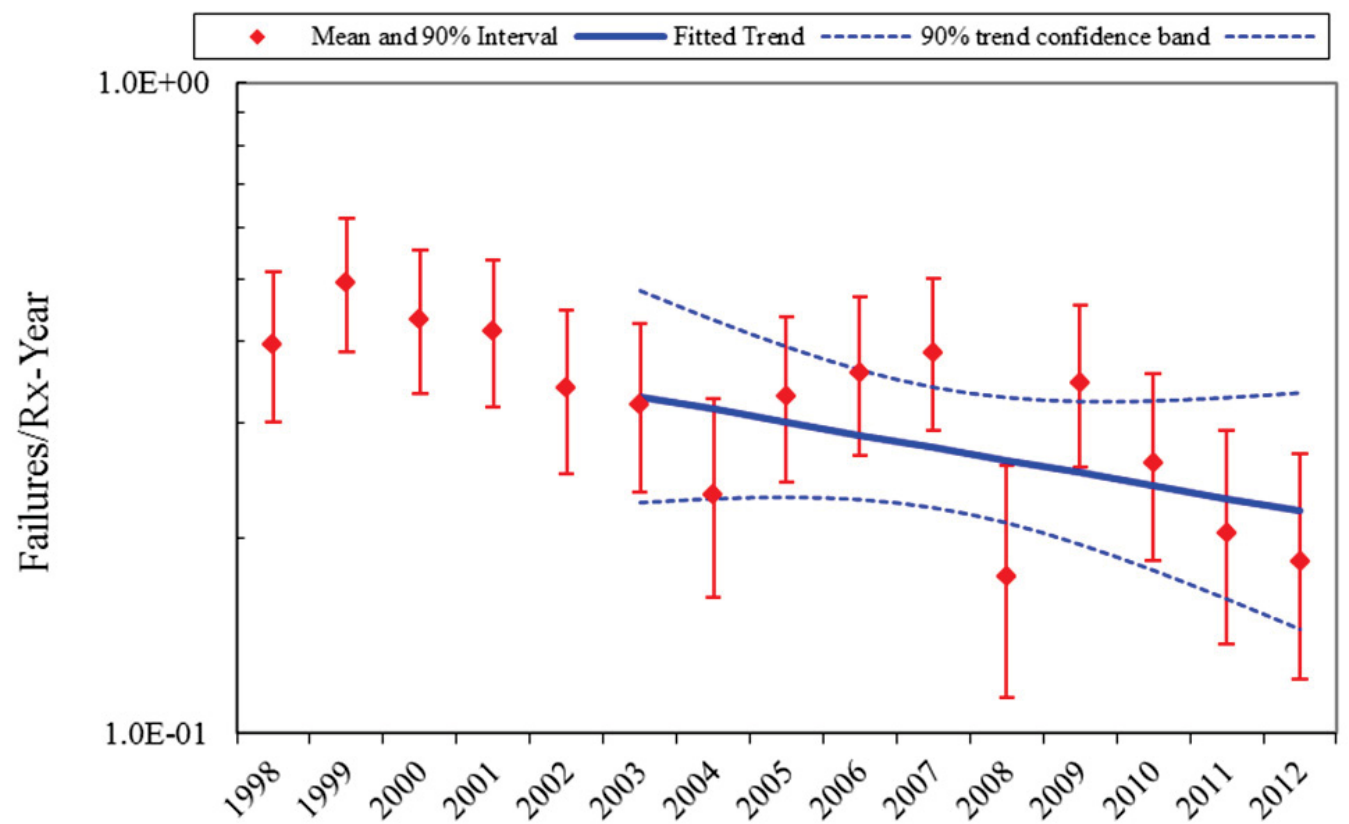

Fiscal Year

CNID, p-value $=0.1697$

All Low Demand MOV FTOC 9-11-2013

Figure 9. Frequency (failures per reactor year) of MOV FTOC events $\leq 20$ demands/yr.

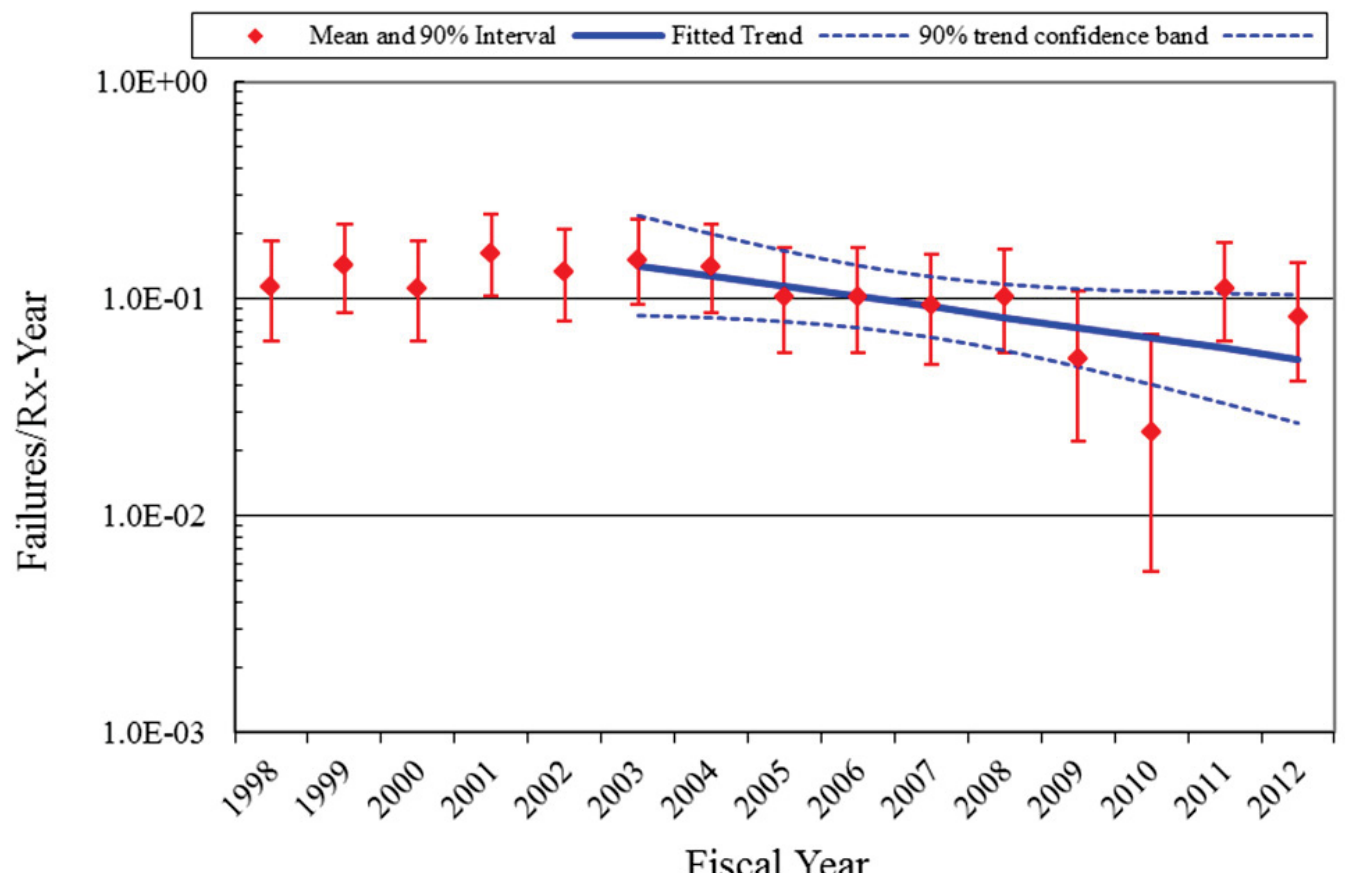

CNID, $p$-value $=0.0421$

All High Demand MOV FTOC 9-11-2013

Figure 10. Frequency (failures per reactor year) of MOV FTOC events $>20$ demands/yr. 


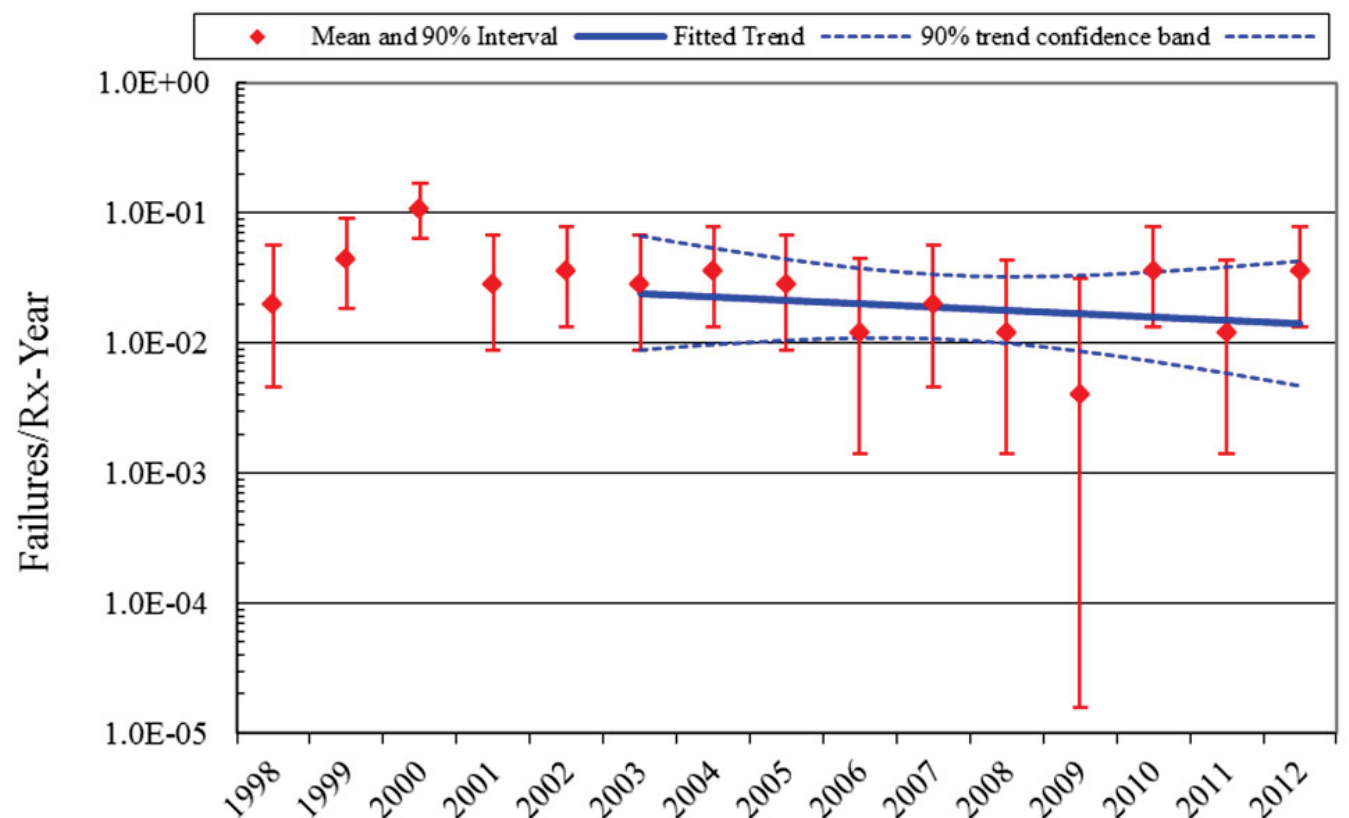

Fiscal Year

CNID, p-value $=0.4703$

All Low Demand MOV FTOP 9-11-2013

Figure 11. Frequency (failures per reactor year) of MOV FTOP events $\leq 20$ demands/yr.

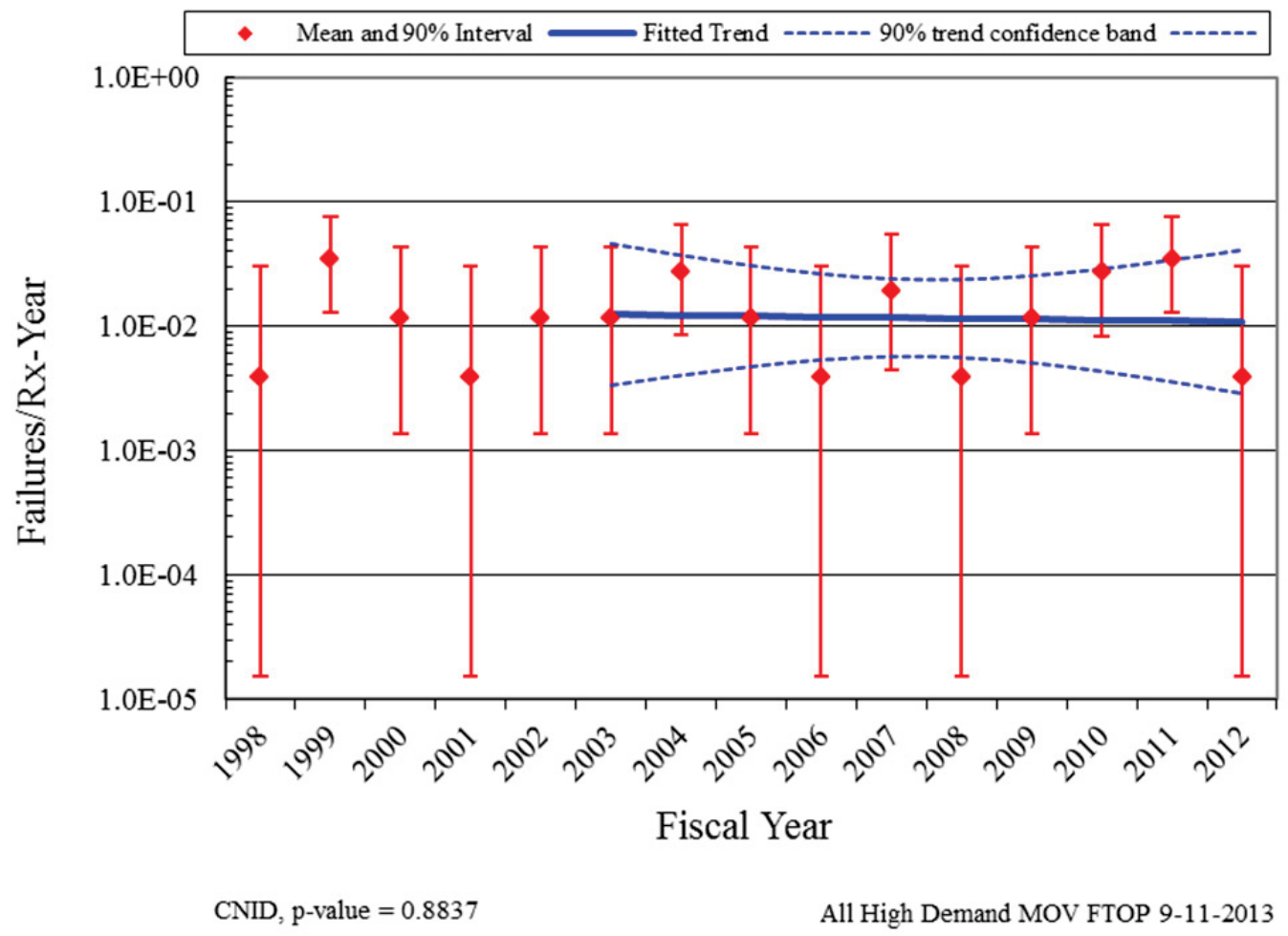

Figure 12. Frequency (failures per reactor year) of MOV FTOP events $>20$ demands/yr. 


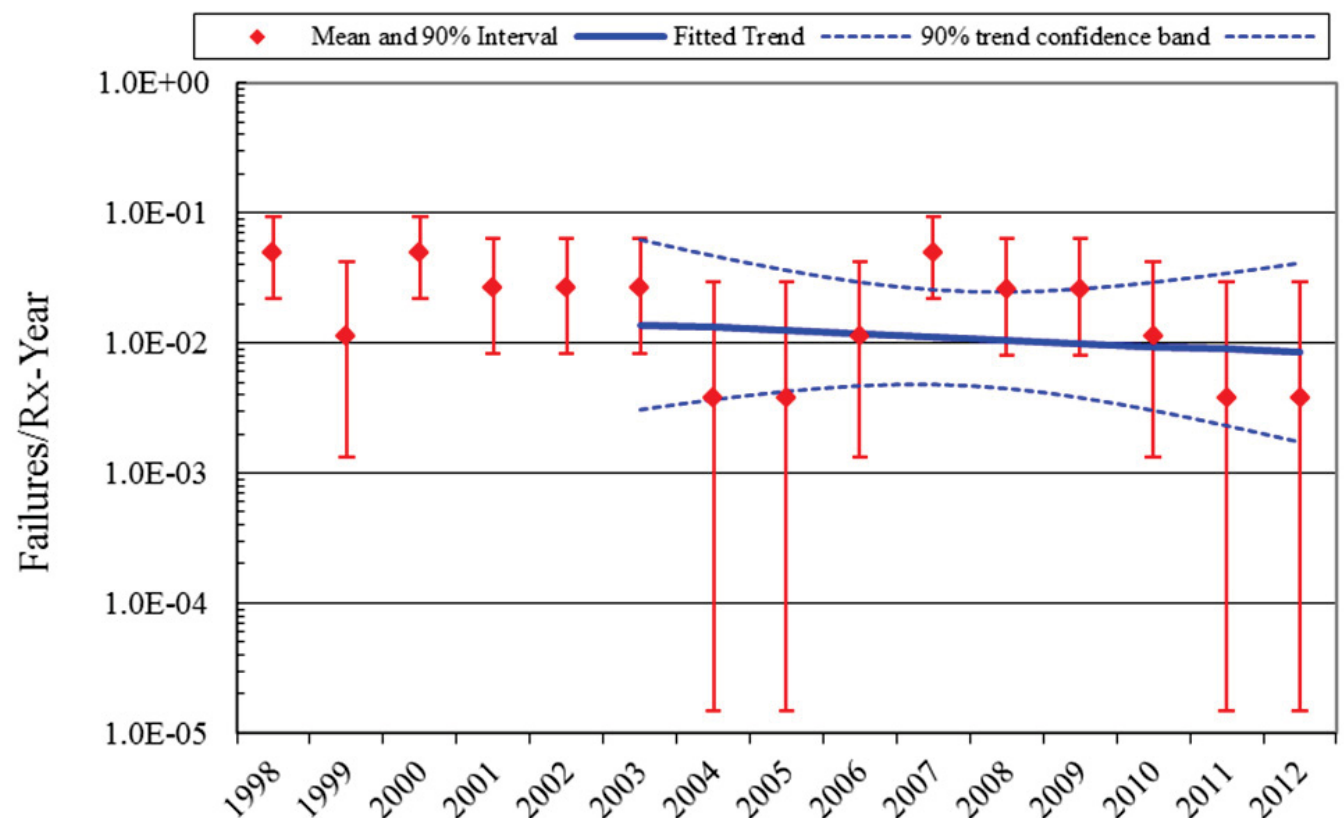

Fiscal Year

CNID, $\mathrm{p}$-value $=0.6481$

All Low Demand MOV SO 9-11-2013

Figure 13. Frequency (failures per reactor year) of MOV SO events $\leq 20$ demands/yr.

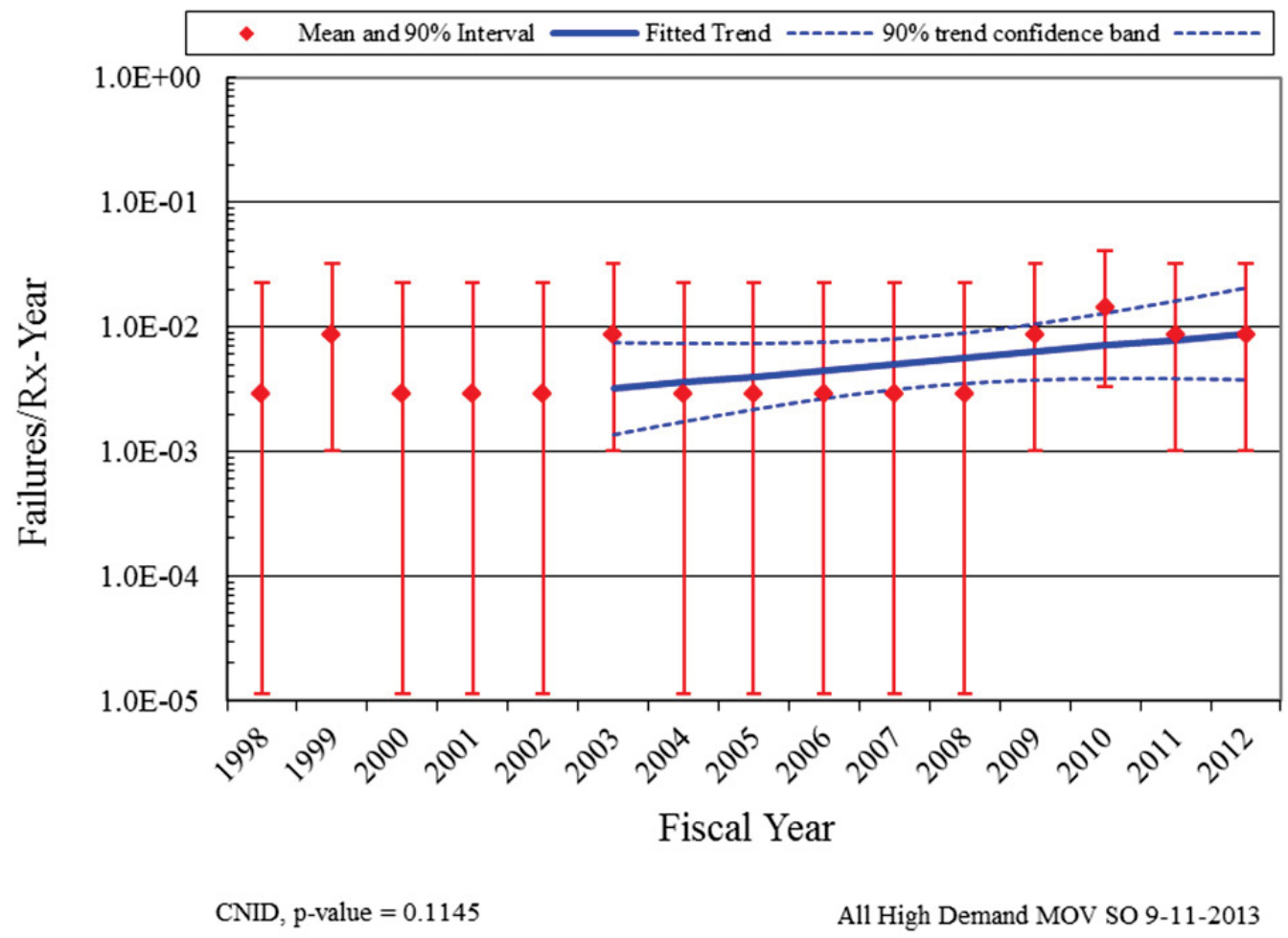

Figure 14. Frequency (failures per reactor year) of MOV SO events $>20$ demands/yr. 


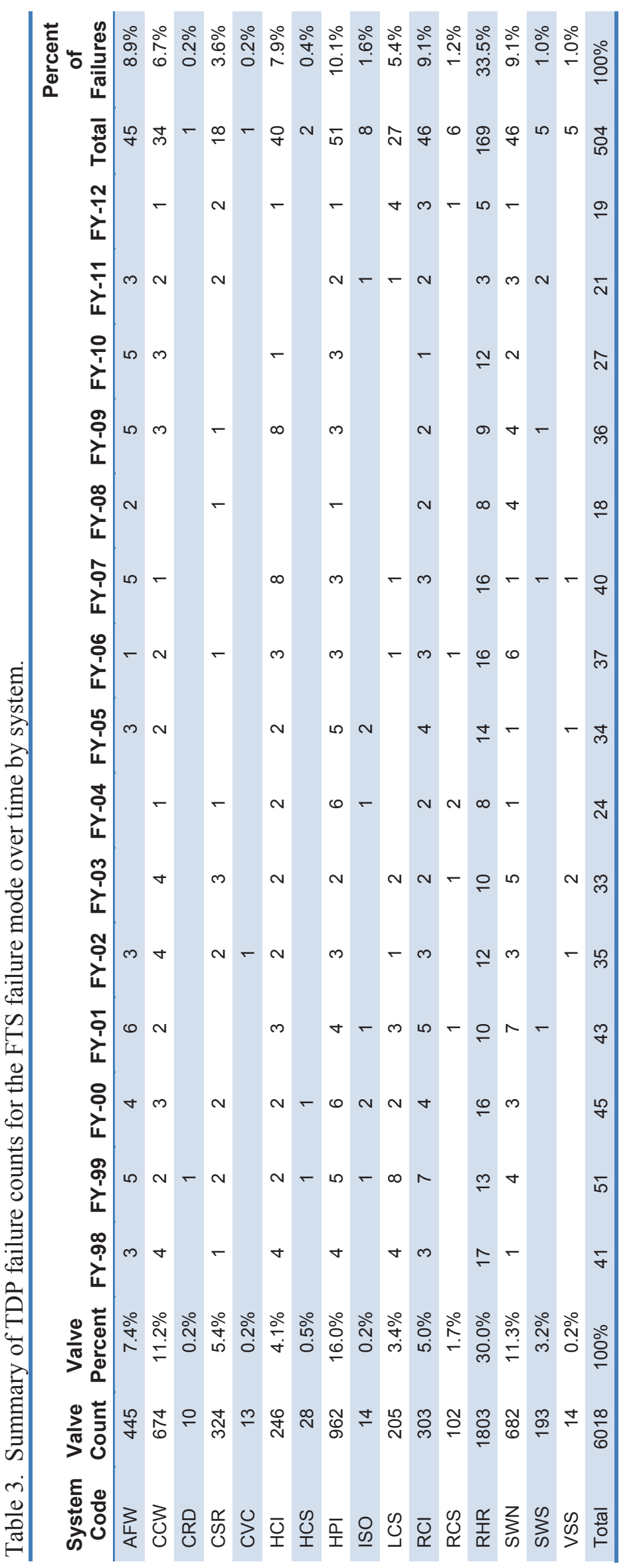




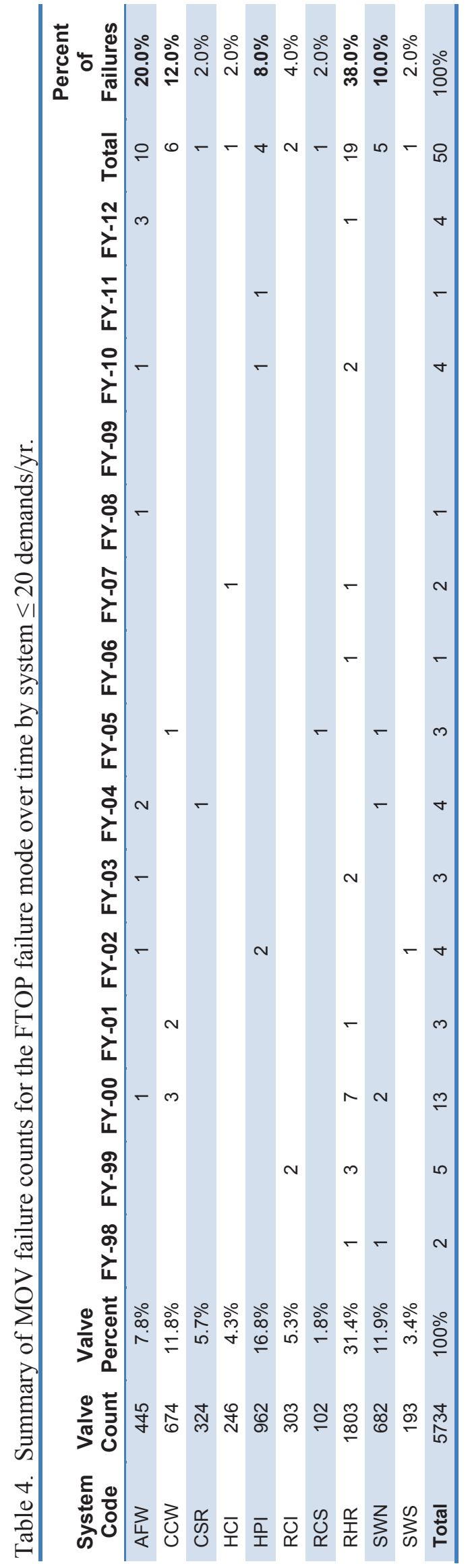

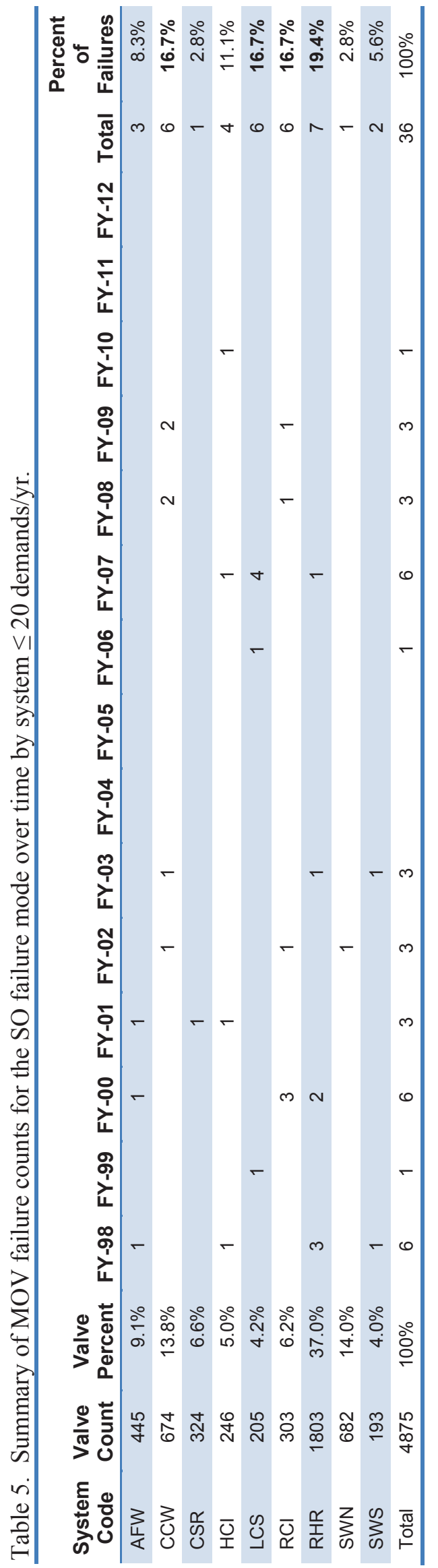

Enhanced Component Performance Study Motor-Onerated Valves 

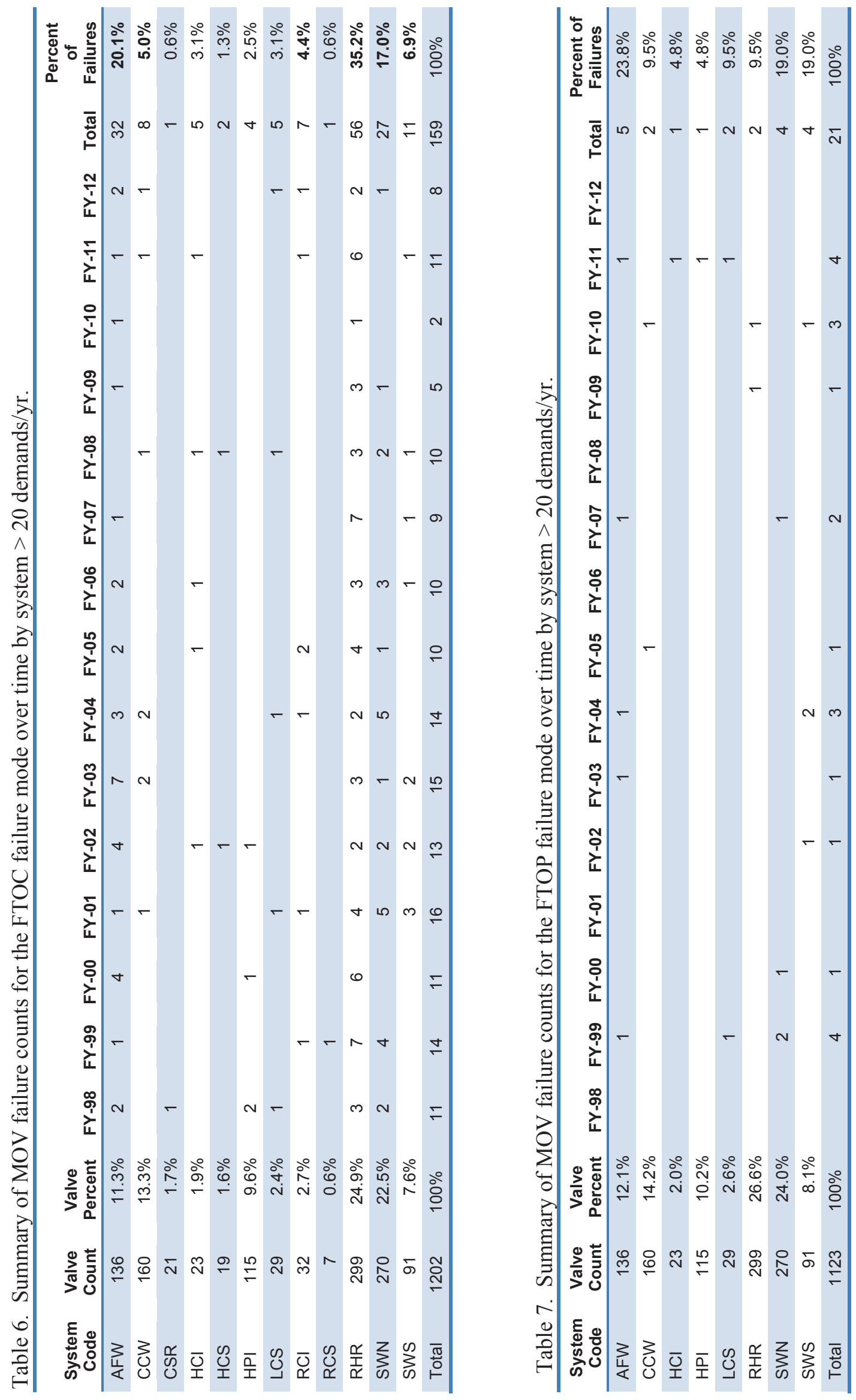


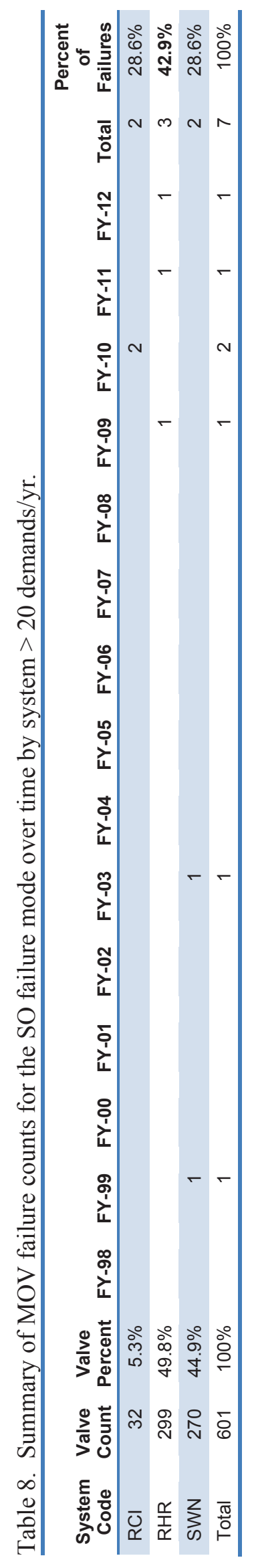

Enhanced Component Performance Study 


\subsection{MOV Engineering Analysis by Failure Modes}

The engineering analysis of MOV failure sub-components, causes, detection methods, and recovery are presented in this section. Each analysis first divides the events into two categories: MOVs with $\leq 20$ demands/year [Low-Demands] and MOVs with > 20 demands/yr [High-Demands].

The second division of the events is by the failure mode determined after EPIX data review by the staff. See Section 5 for more description of failure modes.

MOV sub-component contributions to the three failure modes are presented in Figure 15. The subcomponent contributions are similar to those used in the CCF database. For all three failure modes, the actuator is the largest contributor to the failure rates/probabilities. In the SO failure mode, the valve was shown to have no contribution to the failure rate.

MOV cause group contributions to the three failure modes are presented in Figure 16. The cause groups are similar to those used in the CCF database. Table 9 shows the breakdown of the cause groups with the specific causes that were coded during the data collection. The most likely cause for the FTOC, FTOP, and SO failure modes is grouped as Internal. Internal means that the cause was related to something within the MOV component such as a worn out part or the normal internal environment. Of particular interest is the Human cause group. The human cause group is primarily influenced by maintenance and operating procedures and practices. In addition, the External Cause group is increasing in importance for the SO failure mode.

MOV detection methods to the three failure modes are presented in Figure 17. The most likely detection method for the FTOC failure mode is a testing demand. The FTOP and SO detection modes are heavily influenced by testing and non-test demands.

MOV recovery to the three failure modes are presented in Figure 18. The overall non-recovery to recovery ratio is approximately $13: 1$. 
Table 9. Component failure cause groups.

\begin{tabular}{|c|c|c|}
\hline Group & Specific Cause & Description \\
\hline Design & $\begin{array}{l}\text { Construction/installation error or } \\
\text { inadequacy }\end{array}$ & $\begin{array}{l}\text { Used when a construction or installation error is made } \\
\text { during the original or modification installation. This } \\
\text { includes specification of incorrect component or material. }\end{array}$ \\
\hline Design & Design error or inadequacy & Used when a design error is made. \\
\hline Design & $\begin{array}{l}\text { Manufacturing error or } \\
\text { inadequacy }\end{array}$ & $\begin{array}{l}\text { Used when a manufacturing error is made during } \\
\text { component manufacture. }\end{array}$ \\
\hline External & State of other component & $\begin{array}{l}\text { Used when the cause of a failure is the result of a } \\
\text { component state that is not associated with the } \\
\text { component that failed. An example would be the diesel } \\
\text { failed due to no fuel in the fuel storage tanks. }\end{array}$ \\
\hline External & Ambient environmental stress & $\begin{array}{l}\text { Used when the cause of a failure is the result of an } \\
\text { environmental condition from the location of the } \\
\text { component. }\end{array}$ \\
\hline Human & $\begin{array}{l}\text { Accidental action (unintentional } \\
\text { or undesired human errors) }\end{array}$ & $\begin{array}{l}\text { Used when a human error (during the performance of an } \\
\text { activity) results in an unintentional or undesired action. }\end{array}$ \\
\hline Human & Human action procedure & $\begin{array}{l}\text { Used when the procedure is not followed or the } \\
\text { procedure is incorrect. For example: when a missed step } \\
\text { or incorrect step in a surveillance procedure results in a } \\
\text { component failure. }\end{array}$ \\
\hline Human & Inadequate maintenance & $\begin{array}{l}\text { Used when a human error (during the performance of } \\
\text { maintenance) results in an unintentional or undesired } \\
\text { action. }\end{array}$ \\
\hline Internal & $\begin{array}{l}\text { Internal to component, piece- } \\
\text { part }\end{array}$ & $\begin{array}{l}\text { Used when the cause of a failure is a non-specific result } \\
\text { of a failure internal to the component that failed other } \\
\text { than aging or wear. }\end{array}$ \\
\hline Internal & Internal environment & $\begin{array}{l}\text { The internal environment led to the failure. } \\
\text { Debris/Foreign material as well as an operating medium } \\
\text { chemistry issue. }\end{array}$ \\
\hline Internal & Setpoint drift & $\begin{array}{l}\text { Used when the cause of a failure is the result of setpoint } \\
\text { drift or adjustment. }\end{array}$ \\
\hline Internal & Age/Wear & $\begin{array}{l}\text { Used when the cause of the failure is a non-specific } \\
\text { aging or wear issue. }\end{array}$ \\
\hline Other & Unknown & Used when the cause of the failure is not known. \\
\hline Other & $\begin{array}{l}\text { Other (stated cause does not fit } \\
\text { other categories) }\end{array}$ & $\begin{array}{l}\text { Used when the cause of a failure is provided but it does } \\
\text { not meet any one of the descriptions. }\end{array}$ \\
\hline Procedure & Inadequate procedure & $\begin{array}{l}\text { Used when the cause of a failure is the result of an } \\
\text { inadequate procedure operating or maintenance. }\end{array}$ \\
\hline
\end{tabular}



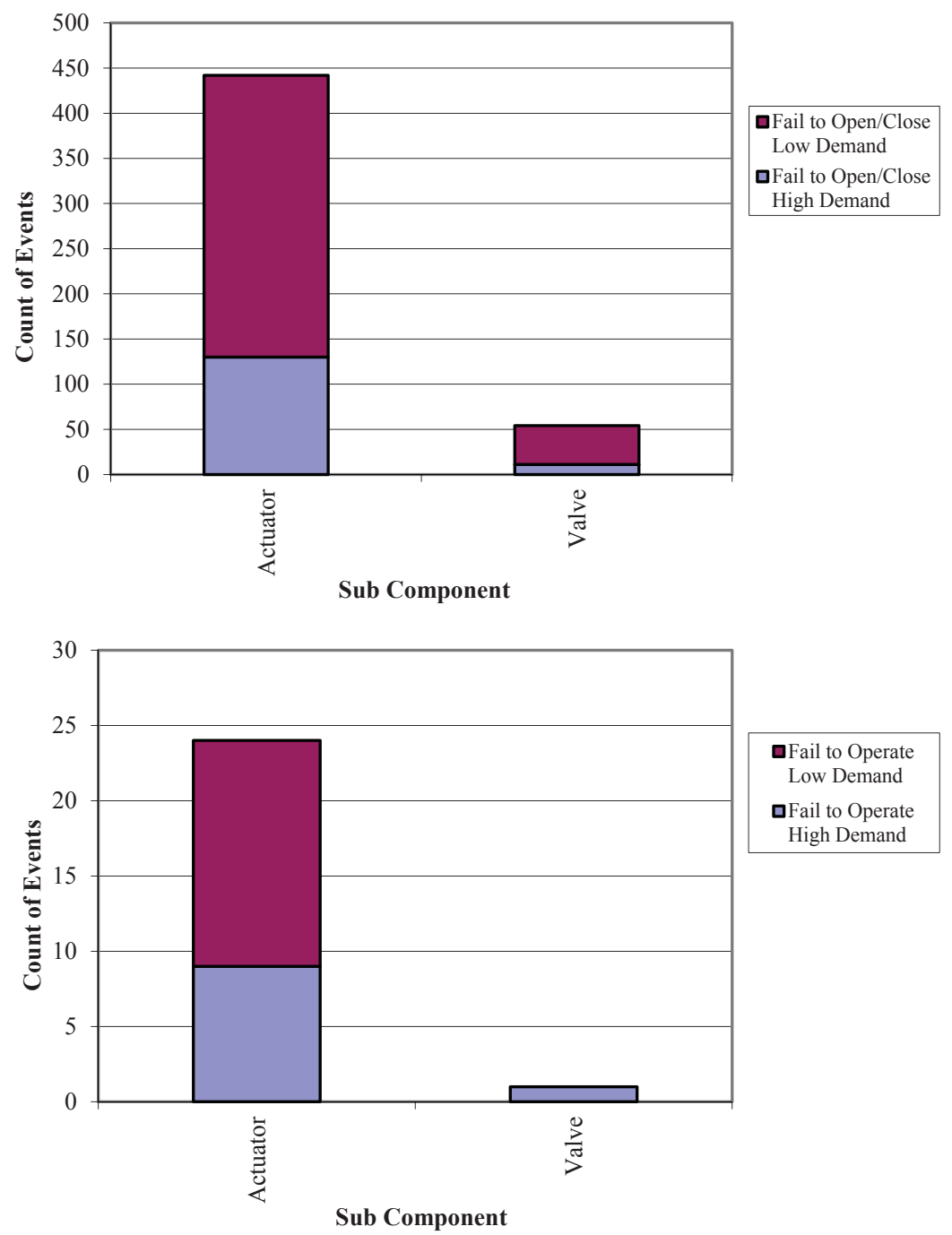

口Fail to Operate Low Demand

口Fail to Operate High Demand

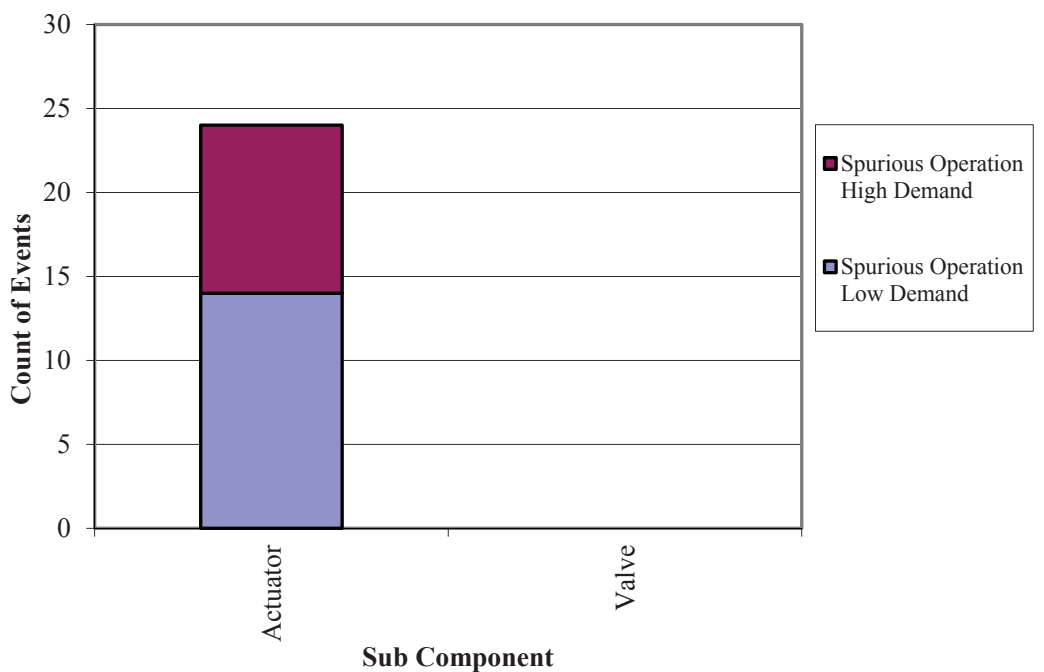

Figure 15. MOV failure breakdown by period, sub component, and failure mode. 


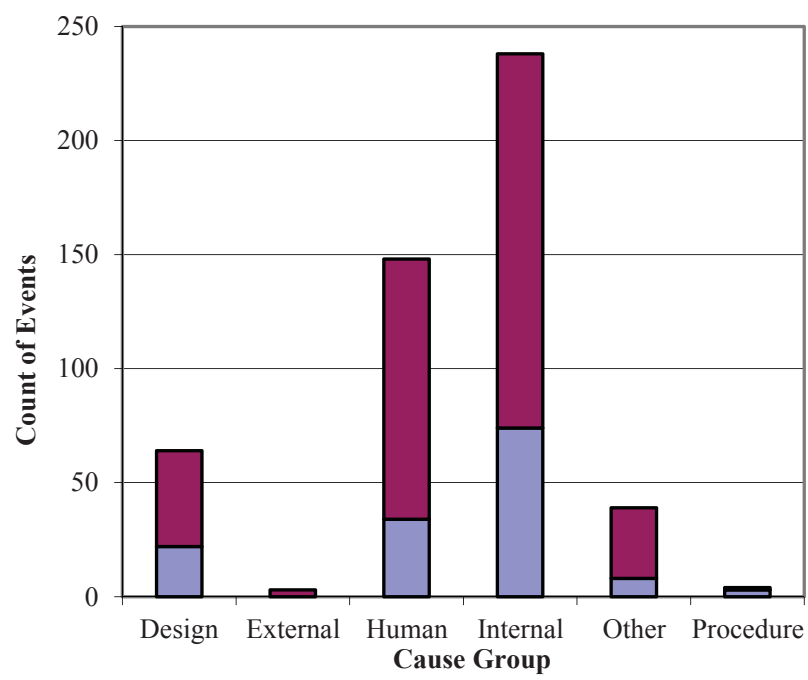

口Fail to Open/Close Low Demand

口Fail to Open/Close High Demand

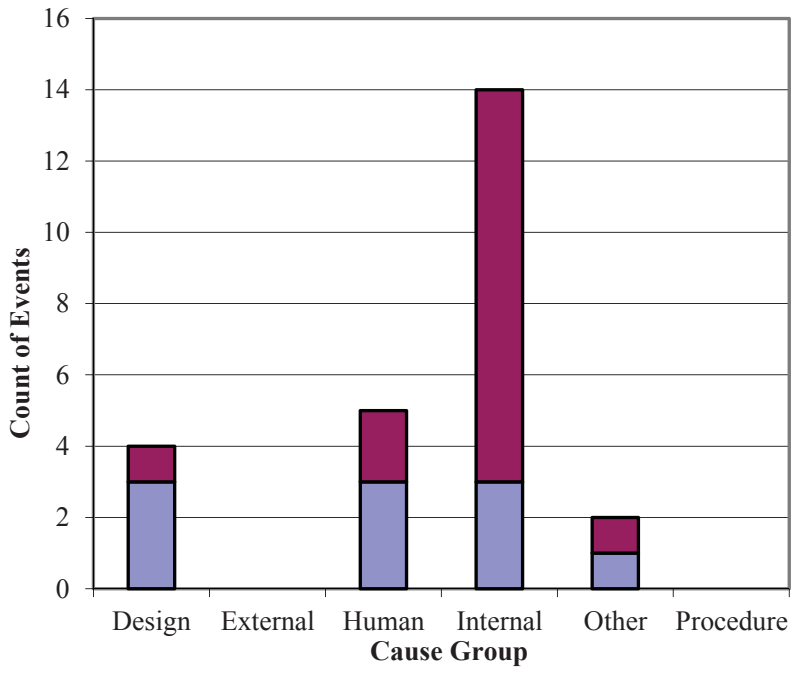

Fail to Operate Low Demand

口Fail to Operate High Demand

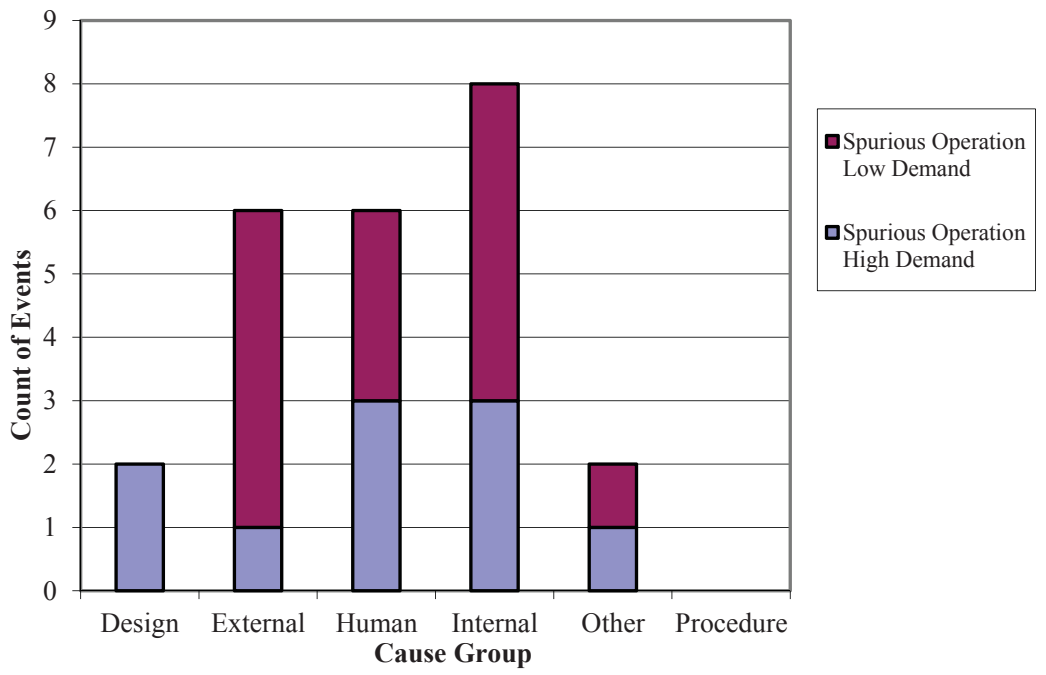

Figure 16. MOV breakdown by time period, cause group, and failure mode. 

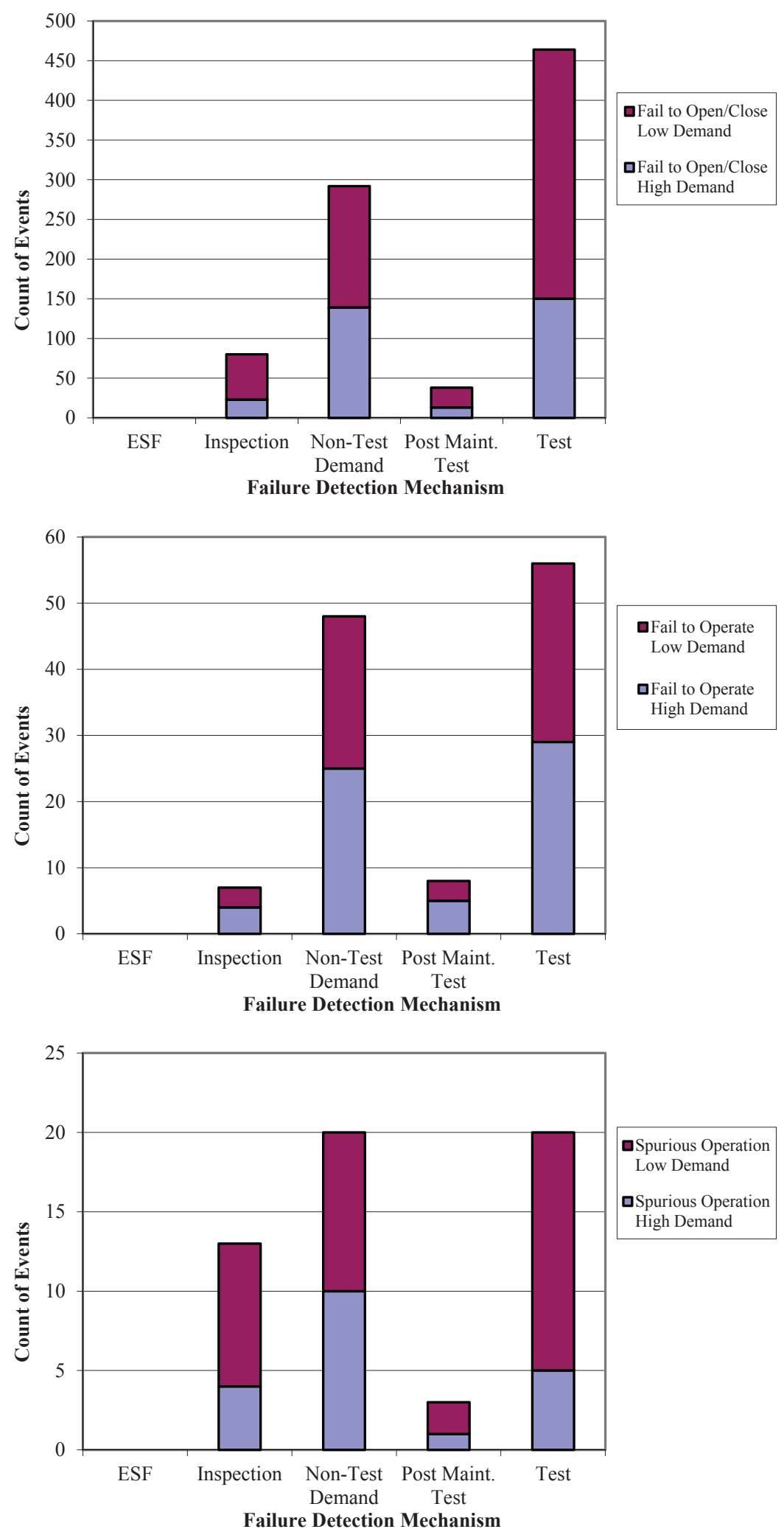

Figure 17. MOV component failure distribution by period, failure mode, and method of detection. 

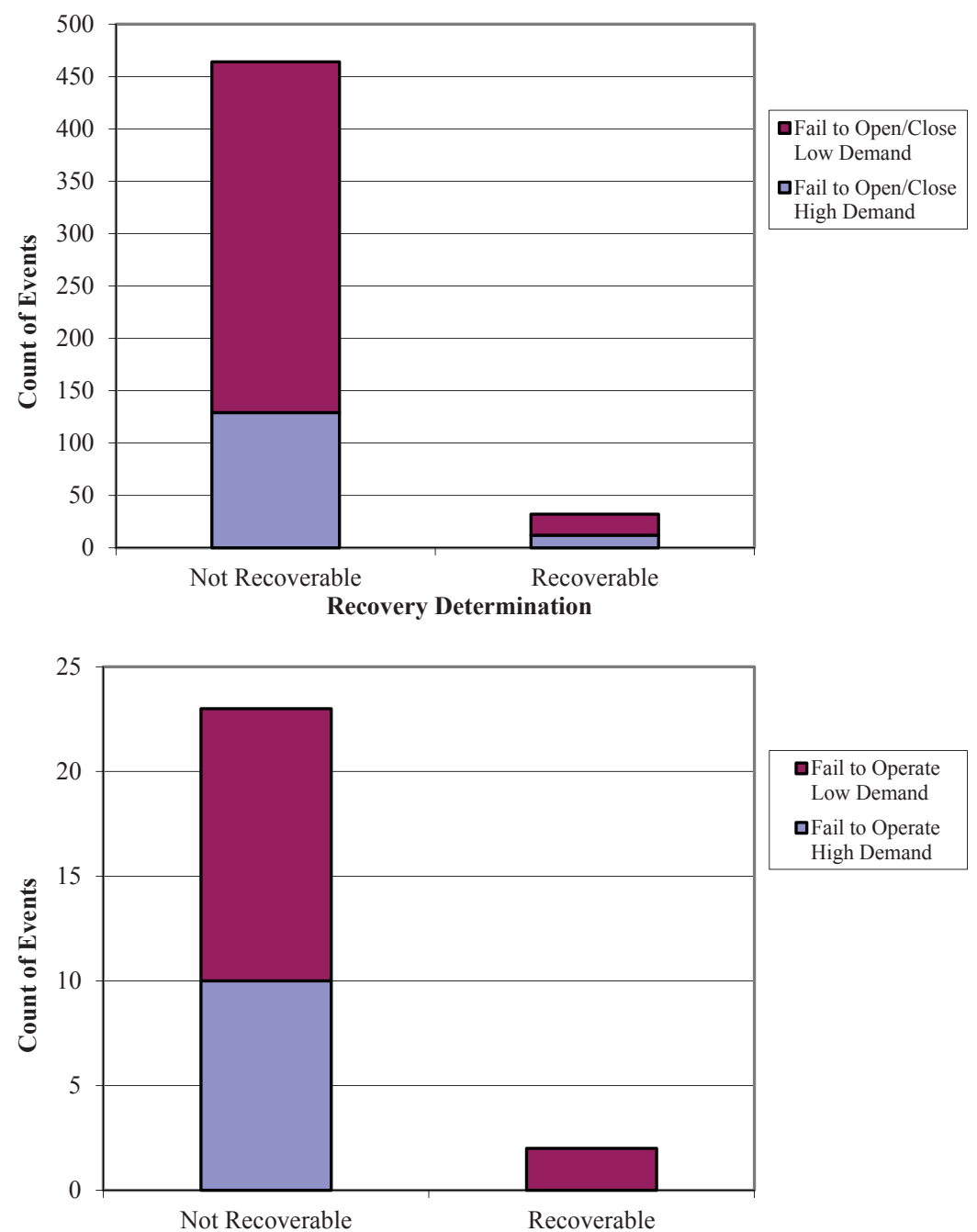
口Fail to Operate Low Demand 口Fail to Operate High Demand

Recovery Determination

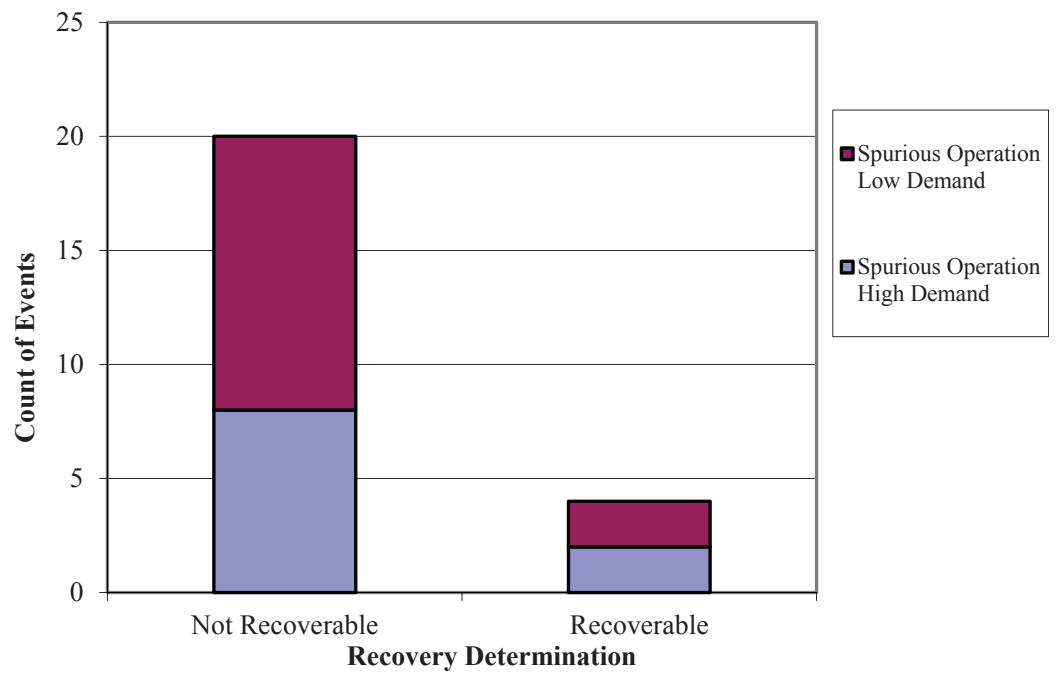

Figure 18. MOV component failure distribution by period, failure mode, and recovery. 


\section{MOV ASSEMBLY DESCRIPTION}

A MOV assembly consists of a valve body and motor-operated sub-components (includes the circuit breaker). The valve body is generally a gate type. The motor-operator is generally a Limitorque or a Rotork ac or de motor actuator.

The piece-parts of the valve body are the stem, packing, and internals. The motor-operator pieceparts include the torque switch, spring pack, limit switch, wiring/contacts, and motor internal and mechanical devices.

Failure modes for the MOV include fail to open/close, which combines the FTOC failure modes into a single category; FTOP, which is a rate-based failure mode that includes FTC for a flow/temperature control device and any other rate-based failure modes not including spurious operation; and SO, which includes spurious opening and spurious closing. 


\section{DATA TABLES}

Table 10. Plot data for industry-wide MOV FTOC trend with $\leq 20$ demands/yr. Figure 1

\begin{tabular}{|c|c|c|c|c|c|c|c|c|}
\hline \multirow[b]{2}{*}{$\begin{array}{c}\text { FYI } \\
\text { Source }\end{array}$} & \multirow[b]{2}{*}{ Failures } & \multirow[b]{2}{*}{ Demands } & \multicolumn{3}{|c|}{ Regression Curve Data Points } & \multicolumn{3}{|c|}{ Plot Trend Error Bar Points } \\
\hline & & & Mean & $\begin{array}{c}\text { Lower } \\
(5 \%)\end{array}$ & $\begin{array}{l}\text { Upper } \\
(95 \%)\end{array}$ & $\begin{array}{c}\text { Lower } \\
(5 \%)\end{array}$ & $\begin{array}{l}\text { Upper } \\
(95 \%)\end{array}$ & Mean \\
\hline \multicolumn{2}{|c|}{2010 Update } & & & & & 1.76E-04 & 2.27E-03 & 9.63E-04 \\
\hline 1998 & 41 & $38,472.8$ & & & & 8.05E-04 & 1.37E-03 & 1.06E-03 \\
\hline 1999 & 51 & $41,207.7$ & & & & $9.62 \mathrm{E}-04$ & $1.55 \mathrm{E}-03$ & 1.23E-03 \\
\hline 2000 & 45 & $41,332.7$ & & & & 8.33E-04 & 1.39E-03 & $1.08 \mathrm{E}-03$ \\
\hline 2001 & 43 & $41,376.5$ & & & & 7.91E-04 & 1.33E-03 & $1.03 \mathrm{E}-03$ \\
\hline 2002 & 35 & $42,027.9$ & & & & 6.16E-04 & 1.10E-03 & 8.32E-04 \\
\hline 2003 & 33 & $42,430.2$ & 8.17E-04 & 5.54E-04 & $1.21 \mathrm{E}-03$ & 5.70E-04 & 1.04E-03 & 7.77E-04 \\
\hline 2004 & 24 & $41,431.9$ & 7.95E-04 & 5.72E-04 & 1.10E-03 & 4.03E-04 & 8.15E-04 & $5.82 \mathrm{E}-04$ \\
\hline 2005 & 34 & $40,844.8$ & 7.73E-04 & 5.86E-04 & 1.02E-03 & $6.13 \mathrm{E}-04$ & 1.10E-03 & 8.31E-04 \\
\hline 2006 & 37 & $37,259.3$ & 7.52E-04 & 5.92E-04 & 9.55E-04 & 7.39E-04 & 1.30E-03 & $9.89 \mathrm{E}-04$ \\
\hline 2007 & 40 & $37,349.9$ & 7.31E-04 & 5.85E-04 & $9.14 \mathrm{E}-04$ & 8.06E-04 & 1.38E-03 & 1.07E-03 \\
\hline 2008 & 18 & $37,627.8$ & 7.11E-04 & 5.64E-04 & 8.98E-04 & $3.14 \mathrm{E}-04$ & 7.12E-04 & 4.83E-04 \\
\hline 2009 & 36 & $37,087.2$ & 6.92E-04 & 5.30E-04 & $9.02 \mathrm{E}-04$ & 7.20E-04 & 1.27E-03 & 9.67E-04 \\
\hline 2010 & 27 & $37,561.9$ & 6.73E-04 & 4.91E-04 & $9.21 \mathrm{E}-04$ & 5.10E-04 & 9.89E-04 & 7.19E-04 \\
\hline 2011 & 21 & $37,123.0$ & 6.54E-04 & 4.51E-04 & 9.50E-04 & 3.83E-04 & 8.16E-04 & 5.69E-04 \\
\hline 2012 & 19 & $36,918.4$ & 6.37E-04 & 4.11E-04 & $9.86 \mathrm{E}-04$ & $3.42 \mathrm{E}-04$ & 7.57E-04 & 5.19E-04 \\
\hline Total & 504 & $590,052.0$ & & & & & & \\
\hline
\end{tabular}


Table 11. Plot data for industry-wide MOV FTOC trend with $>20$ demands/yr. Figure 2

\begin{tabular}{|c|c|c|c|c|c|c|c|c|}
\hline \multirow[b]{2}{*}{$\begin{array}{l}\text { FYI } \\
\text { Source }\end{array}$} & \multirow[b]{2}{*}{ Failures } & \multirow[b]{2}{*}{ Demands } & \multicolumn{3}{|c|}{ Regression Curve Data Points } & \multicolumn{3}{|c|}{ Plot Trend Error Bar Points } \\
\hline & & & Mean & $\begin{array}{c}\text { Lower } \\
(5 \%)\end{array}$ & $\begin{array}{l}\text { Upper } \\
(95 \%)\end{array}$ & $\begin{array}{c}\text { Lower } \\
(5 \%)\end{array}$ & $\begin{array}{l}\text { Upper } \\
(95 \%)\end{array}$ & Mean \\
\hline \multicolumn{2}{|c|}{2010 Update } & & & & & 1.76E-04 & 2.27E-03 & 9.63E-04 \\
\hline 1998 & 11 & $38,628.1$ & & & & 1.60E-04 & 4.61E-04 & $2.82 \mathrm{E}-04$ \\
\hline 1999 & 14 & $41,300.8$ & & & & 2.03E-04 & 5.17E-04 & 3.33E-04 \\
\hline 2000 & 11 & $43,550.0$ & & & & 1.43E-04 & 4.11E-04 & $2.51 \mathrm{E}-04$ \\
\hline 2001 & 16 & $50,246.5$ & & & & 1.99E-04 & 4.75E-04 & 3.14E-04 \\
\hline 2002 & 13 & $39,778.1$ & & & & 1.92E-04 & 5.07E-04 & $3.21 \mathrm{E}-04$ \\
\hline 2003 & 15 & $40,534.0$ & 3.29E-04 & 1.90E-04 & 5.67E-04 & $2.25 \mathrm{E}-04$ & 5.54E-04 & 3.63E-04 \\
\hline 2004 & 14 & $42,664.8$ & 2.95E-04 & 1.86E-04 & 4.66E-04 & 1.97E-04 & 5.01E-04 & 3.23E-04 \\
\hline 2005 & 10 & $42,596.1$ & 2.64E-04 & 1.80E-04 & 3.89E-04 & 1.29E-04 & 3.92E-04 & 2.34E-04 \\
\hline 2006 & 10 & $42,194.5$ & 2.37E-04 & 1.69E-04 & 3.33E-04 & 1.30E-04 & 3.96E-04 & 2.36E-04 \\
\hline 2007 & 9 & $42,598.0$ & 2.13E-04 & 1.54E-04 & 2.95E-04 & 1.13E-04 & 3.64E-04 & $2.12 \mathrm{E}-04$ \\
\hline 2008 & 10 & $42,091.9$ & 1.91E-04 & 1.34E-04 & 2.72E-04 & 1.31E-04 & 3.97E-04 & 2.37E-04 \\
\hline 2009 & 5 & $41,783.3$ & 1.71E-04 & 1.13E-04 & 2.59E-04 & 5.20E-05 & 2.54E-04 & 1.25E-04 \\
\hline 2010 & 2 & $42,270.3$ & 1.54E-04 & 9.40E-05 & $2.51 \mathrm{E}-04$ & 1.29E-05 & 1.58E-04 & 5.62E-05 \\
\hline 2011 & 11 & $42,054.5$ & 1.38E-04 & 7.69E-05 & 2.47E-04 & 1.48E-04 & 4.25E-04 & 2.60E-04 \\
\hline 2012 & 8 & $41,121.1$ & 1.24E-04 & $6.25 \mathrm{E}-05$ & $2.45 \mathrm{E}-04$ & 1.00E-04 & 3.48E-04 & 1.96E-04 \\
\hline Total & 159 & $633,412.1$ & & & & & & \\
\hline
\end{tabular}


Table 12. Plot data for industry-wide MOV FTOP trend with $\leq 20$ demands/yr. Figure 3

\begin{tabular}{|c|c|c|c|c|c|c|c|c|}
\hline \multirow[b]{2}{*}{$\begin{array}{c}\text { FYI } \\
\text { Source }\end{array}$} & \multirow[b]{2}{*}{ Failures } & \multirow[b]{2}{*}{ Demands } & \multicolumn{3}{|c|}{ Regression Curve Data Points } & \multicolumn{3}{|c|}{ Plot Trend Error Bar Points } \\
\hline & & & Mean & $\begin{array}{l}\text { Lower } \\
(5 \%)\end{array}$ & $\begin{array}{l}\text { Upper } \\
(95 \%)\end{array}$ & $\begin{array}{l}\text { Lower } \\
(5 \%)\end{array}$ & $\begin{array}{l}\text { Upper } \\
(95 \%)\end{array}$ & Mean \\
\hline \multicolumn{2}{|c|}{2010 Update } & & & & & 7.40E-09 & $1.74 \mathrm{E}-07$ & 6.62E-08 \\
\hline 1998 & 2 & $52,463,640.0$ & & & & 8.99E-09 & 1.10E-07 & 3.93E-08 \\
\hline 1999 & 5 & $52,621,320.0$ & & & & 3.58E-08 & $1.75 \mathrm{E}-07$ & 8.61E-08 \\
\hline 2000 & 13 & $52,656,360.0$ & & & & $1.26 \mathrm{E}-07$ & 3.33E-07 & 2.11E-07 \\
\hline 2001 & 3 & $52,638,840.0$ & & & & 1.70E-08 & $1.32 \mathrm{E}-07$ & 5.48E-08 \\
\hline 2002 & 4 & $52,595,040.0$ & & & & 2.61E-08 & $1.54 \mathrm{E}-07$ & 7.05E-08 \\
\hline 2003 & 3 & $52,638,840.0$ & 4.76E-08 & $1.74 \mathrm{E}-08$ & 1.31E-07 & $1.70 \mathrm{E}-08$ & $1.32 \mathrm{E}-07$ & $5.48 \mathrm{E}-08$ \\
\hline 2004 & 4 & $52,586,280.0$ & 4.49E-08 & 1.91E-08 & $1.05 \mathrm{E}-07$ & 2.61E-08 & $1.54 \mathrm{E}-07$ & 7.05E-08 \\
\hline 2005 & 3 & $52,621,320.0$ & 4.23E-08 & 2.06E-08 & 8.66E-08 & 1.70E-08 & 1.33E-07 & 5.48E-08 \\
\hline 2006 & 1 & $52,665,120.0$ & 3.98E-08 & $2.15 \mathrm{E}-08$ & 7.38E-08 & 2.75E-09 & 8.66E-08 & 2.35E-08 \\
\hline 2007 & 2 & $52,647,600.0$ & 3.75E-08 & 2.12E-08 & 6.63E-08 & 8.97E-09 & 1.10E-07 & 3.91E-08 \\
\hline 2008 & 1 & $52,682,640.0$ & 3.53E-08 & 1.96E-08 & 6.37E-08 & 2.75E-09 & 8.66E-08 & 2.35E-08 \\
\hline 2009 & 0 & $52,743,960.0$ & 3.33E-08 & 1.71E-08 & $6.50 \mathrm{E}-08$ & 3.07E-11 & 6.11E-08 & 7.82E-09 \\
\hline 2010 & 4 & $52,717,680.0$ & 3.14E-08 & 1.42E-08 & 6.92E-08 & 2.60E-08 & $1.54 \mathrm{E}-07$ & 7.04E-08 \\
\hline 2011 & 1 & $53,252,040.0$ & 2.96E-08 & 1.16E-08 & 7.56E-08 & 2.73E-09 & 8.59E-08 & 2.33E-08 \\
\hline 2012 & 4 & $52,866,600.0$ & 2.79E-08 & 9.24E-09 & 8.40E-08 & 2.59E-08 & $1.54 \mathrm{E}-07$ & 7.02E-08 \\
\hline Total & 50 & $790,397,280.0$ & & & & & & \\
\hline
\end{tabular}


Table 13. Plot data for industry-wide MOV FTOP trend with $>20$ demands/yr. Figure 4

\begin{tabular}{|c|c|c|c|c|c|c|c|c|}
\hline \multirow[b]{2}{*}{$\begin{array}{c}\text { FYI } \\
\text { Source }\end{array}$} & \multirow[b]{2}{*}{ Failures } & \multirow[b]{2}{*}{ Demands } & \multicolumn{3}{|c|}{ Regression Curve Data Points } & \multicolumn{3}{|c|}{ Plot Trend Error Bar Points } \\
\hline & & & Mean & $\begin{array}{l}\text { Lower } \\
(5 \%)\end{array}$ & $\begin{array}{l}\text { Upper } \\
(95 \%)\end{array}$ & $\begin{array}{l}\text { Lower } \\
(5 \%)\end{array}$ & $\begin{array}{l}\text { Upper } \\
(95 \%)\end{array}$ & Mean \\
\hline \multicolumn{2}{|c|}{2010 Update } & & & & & 7.40E-09 & 1.74E-07 & $6.62 \mathrm{E}-08$ \\
\hline 1998 & 0 & $10,380,600.0$ & & & & $1.42 \mathrm{E}-10$ & 2.83E-07 & 3.62E-08 \\
\hline 1999 & 4 & $10,547,040.0$ & & & & 1.19E-07 & 7.03E-07 & $3.22 \mathrm{E}-07$ \\
\hline 2000 & 1 & $10,564,560.0$ & & & & 1.26E-08 & 3.95E-07 & 1.07E-07 \\
\hline 2001 & 0 & $10,547,040.0$ & & & & $1.41 \mathrm{E}-10$ & 2.79E-07 & 3.57E-08 \\
\hline 2002 & 1 & $10,555,800.0$ & & & & 1.26E-08 & 3.95E-07 & 1.07E-07 \\
\hline 2003 & 1 & $10,564,560.0$ & 1.14E-07 & 3.08E-08 & $4.22 \mathrm{E}-07$ & $1.26 \mathrm{E}-08$ & 3.95E-07 & 1.07E-07 \\
\hline 2004 & 3 & $10,599,600.0$ & 1.12E-07 & 3.70E-08 & 3.41E-07 & 7.72E-08 & $6.02 \mathrm{E}-07$ & 2.49E-07 \\
\hline 2005 & 1 & $10,608,360.0$ & 1.11E-07 & 4.35E-08 & 2.81E-07 & $1.25 \mathrm{E}-08$ & 3.94E-07 & 1.07E-07 \\
\hline 2006 & 0 & $10,599,600.0$ & 1.09E-07 & 4.92E-08 & 2.41E-07 & $1.40 \mathrm{E}-10$ & 2.78E-07 & $3.56 \mathrm{E}-08$ \\
\hline 2007 & 2 & $10,617,120.0$ & 1.07E-07 & 5.23E-08 & 2.20E-07 & 4.07E-08 & $5.00 \mathrm{E}-07$ & $1.78 \mathrm{E}-07$ \\
\hline 2008 & 0 & $10,722,240.0$ & 1.06E-07 & 5.13E-08 & 2.17E-07 & 1.39E-10 & 2.76E-07 & $3.53 \mathrm{E}-08$ \\
\hline 2009 & 1 & $10,669,680.0$ & $1.04 \mathrm{E}-07$ & 4.65E-08 & 2.32E-07 & $1.25 \mathrm{E}-08$ & 3.92E-07 & 1.06E-07 \\
\hline 2010 & 3 & $10,713,480.0$ & 1.02E-07 & 3.97E-08 & 2.64E-07 & 7.66E-08 & 5.98E-07 & 2.47E-07 \\
\hline 2011 & 4 & $10,879,920.0$ & 1.01E-07 & 3.27E-08 & 3.11E-07 & 1.16E-07 & 6.87E-07 & 3.14E-07 \\
\hline 2012 & 0 & $10,757,280.0$ & 9.93E-08 & 2.64E-08 & $3.74 \mathrm{E}-07$ & $1.38 \mathrm{E}-10$ & $2.75 \mathrm{E}-07$ & $3.52 \mathrm{E}-08$ \\
\hline Total & 21 & $159,326,880.0$ & & & & & & \\
\hline
\end{tabular}

Table 14. Plot data for industry-wide MOV SO trend with $\leq 20$ demands/yr. Figure 5

\begin{tabular}{|c|c|c|c|c|c|c|c|c|}
\hline \multirow[b]{2}{*}{$\begin{array}{c}\text { FYI } \\
\text { Source }\end{array}$} & \multirow[b]{2}{*}{ Failures } & \multirow[b]{2}{*}{ Hours } & \multicolumn{3}{|c|}{ Regression Curve Data Points } & \multicolumn{3}{|c|}{ Plot Trend Error Bar Points } \\
\hline & & & Mean & $\begin{array}{l}\text { Lower } \\
(5 \%)\end{array}$ & $\begin{array}{l}\text { Upper } \\
(95 \%)\end{array}$ & $\begin{array}{l}\text { Lower } \\
(5 \%)\end{array}$ & $\begin{array}{l}\text { Upper } \\
(95 \%)\end{array}$ & Mean \\
\hline \multicolumn{2}{|c|}{2010 Update } & & & & & $2.54 \mathrm{E}-10$ & $1.24 \mathrm{E}-07$ & 3.39E-08 \\
\hline 1998 & 6 & $52,463,640.0$ & & & & 4.36E-08 & 1.85E-07 & $9.62 \mathrm{E}-08$ \\
\hline 1999 & 1 & $52,621,320.0$ & & & & 2.60E-09 & 8.18E-08 & $2.22 \mathrm{E}-08$ \\
\hline 2000 & 6 & $52,656,360.0$ & & & & 4.35E-08 & 1.85E-07 & $9.60 \mathrm{E}-08$ \\
\hline 2001 & 3 & $52,638,840.0$ & & & & 1.60E-08 & 1.25E-07 & 5.17E-08 \\
\hline 2002 & 3 & $52,595,040.0$ & & & & $1.60 \mathrm{E}-08$ & $1.25 \mathrm{E}-07$ & 5.17E-08 \\
\hline 2003 & 3 & $52,638,840.0$ & $2.72 \mathrm{E}-08$ & 6.03E-09 & $1.22 \mathrm{E}-07$ & $1.60 \mathrm{E}-08$ & 1.25E-07 & 5.17E-08 \\
\hline 2004 & 0 & $52,586,280.0$ & 2.57E-08 & 7.19E-09 & 9.19E-08 & 2.91E-11 & $5.78 \mathrm{E}-08$ & 7.39E-09 \\
\hline 2005 & 0 & $52,621,320.0$ & $2.44 \mathrm{E}-08$ & 8.34E-09 & 7.11E-08 & $2.90 \mathrm{E}-11$ & 5.77E-08 & 7.39E-09 \\
\hline 2006 & 1 & $52,665,120.0$ & 2.31E-08 & $9.21 \mathrm{E}-09$ & 5.77E-08 & 2.60E-09 & 8.17E-08 & $2.21 \mathrm{E}-08$ \\
\hline 2007 & 6 & $52,647,600.0$ & 2.18E-08 & 9.44E-09 & 5.05E-08 & 4.35E-08 & 1.85E-07 & $9.60 \mathrm{E}-08$ \\
\hline 2008 & 3 & $52,682,640.0$ & 2.07E-08 & 8.79E-09 & 4.86E-08 & 1.60E-08 & $1.25 \mathrm{E}-07$ & 5.17E-08 \\
\hline 2009 & 3 & $52,743,960.0$ & 1.96E-08 & 7.47E-09 & 5.13E-08 & 1.60E-08 & $1.25 \mathrm{E}-07$ & 5.16E-08 \\
\hline 2010 & 1 & $52,717,680.0$ & 1.85E-08 & 5.95E-09 & 5.77E-08 & 2.60E-09 & 8.17E-08 & $2.21 \mathrm{E}-08$ \\
\hline 2011 & 0 & $53,252,040.0$ & 1.76E-08 & 4.55E-09 & 6.77E-08 & 2.88E-11 & 5.72E-08 & 7.32E-09 \\
\hline 2012 & 0 & $52,866,600.0$ & 1.66E-08 & 3.40E-09 & 8.13E-08 & 2.89E-11 & 5.75E-08 & 7.36E-09 \\
\hline Total & 36 & $790,397,280.0$ & & & & & & \\
\hline
\end{tabular}


Table 15. Plot data for industry-wide MOV SO trend, > 20 demands/yr. Figure 6

\begin{tabular}{|c|c|c|c|c|c|c|c|c|}
\hline \multirow[b]{2}{*}{$\begin{array}{c}\text { FYI } \\
\text { Source }\end{array}$} & \multirow[b]{2}{*}{$\begin{array}{c}\text { Failure } \\
\mathbf{s}\end{array}$} & \multirow[b]{2}{*}{ Hours } & \multicolumn{3}{|c|}{ Regression Curve Data Points } & \multicolumn{3}{|c|}{ Plot Trend Error Bar Points } \\
\hline & & & Mean & $\begin{array}{l}\text { Lower } \\
(5 \%)\end{array}$ & $\begin{array}{l}\text { Upper } \\
(95 \%)\end{array}$ & $\begin{array}{l}\text { Lower } \\
(5 \%)\end{array}$ & $\begin{array}{l}\text { Upper } \\
(95 \%)\end{array}$ & Mean \\
\hline \multicolumn{2}{|c|}{2010 Update } & & & & & $2.54 \mathrm{E}-10$ & $1.24 \mathrm{E}-07$ & 3.39E-08 \\
\hline 1998 & 0 & $10,380,600.0$ & & & & 1.06E-10 & 2.10E-07 & 2.69E-08 \\
\hline 1999 & 1 & $10,547,040.0$ & & & & $9.38 \mathrm{E}-09$ & 2.95E-07 & 8.00E-08 \\
\hline 2000 & 0 & $10,564,560.0$ & & & & $1.05 \mathrm{E}-10$ & 2.08E-07 & 2.66E-08 \\
\hline 2001 & 0 & $10,547,040.0$ & & & & $1.05 \mathrm{E}-10$ & 2.08E-07 & 2.67E-08 \\
\hline 2002 & 0 & $10,555,800.0$ & & & & $1.05 \mathrm{E}-10$ & 2.08E-07 & 2.66E-08 \\
\hline 2003 & 1 & $10,564,560.0$ & 2.94E-08 & $1.25 \mathrm{E}-08$ & $6.88 \mathrm{E}-08$ & 9.37E-09 & 2.95E-07 & 7.99E-08 \\
\hline 2004 & 0 & $10,599,600.0$ & $3.28 \mathrm{E}-08$ & $1.59 \mathrm{E}-08$ & 6.77E-08 & $1.05 \mathrm{E}-10$ & 2.08E-07 & 2.66E-08 \\
\hline 2005 & 0 & $10,608,360.0$ & 3.67E-08 & 2.00E-08 & $6.75 \mathrm{E}-08$ & $1.04 \mathrm{E}-10$ & 2.08E-07 & 2.66E-08 \\
\hline 2006 & 0 & $10,599,600.0$ & 4.11E-08 & $2.44 \mathrm{E}-08$ & 6.90E-08 & $1.05 \mathrm{E}-10$ & $2.08 \mathrm{E}-07$ & $2.66 \mathrm{E}-08$ \\
\hline 2007 & 0 & $10,617,120.0$ & 4.59E-08 & 2.88E-08 & 7.33E-08 & $1.04 \mathrm{E}-10$ & 2.08E-07 & 2.66E-08 \\
\hline 2008 & 0 & $10,722,240.0$ & 5.14E-08 & 3.22E-08 & 8.19E-08 & $1.04 \mathrm{E}-10$ & 2.06E-07 & 2.64E-08 \\
\hline 2009 & 1 & $10,669,680.0$ & 5.75E-08 & 3.43E-08 & 9.63E-08 & 9.32E-09 & 2.93E-07 & 7.94E-08 \\
\hline 2010 & 2 & $10,713,480.0$ & 6.43E-08 & 3.51E-08 & 1.18E-07 & 3.03E-08 & 3.72E-07 & $1.32 \mathrm{E}-07$ \\
\hline 2011 & 1 & $10,879,920.0$ & 7.19E-08 & 3.50E-08 & $1.48 \mathrm{E}-07$ & 9.22E-09 & 2.90E-07 & 7.86E-08 \\
\hline 2012 & 1 & $10,757,280.0$ & 8.04E-08 & $3.45 \mathrm{E}-08$ & 1.87E-07 & 9.27E-09 & 2.92E-07 & 7.91E-08 \\
\hline Total & 7 & $159,326,880.0$ & & & & & & \\
\hline
\end{tabular}

Table 16. Plot data for frequency (events per reactor year) of MOV operation demands with $\leq$ 20 demands/yr. Figure 7

\begin{tabular}{|c|c|c|c|c|c|c|c|c|}
\hline \multirow[b]{2}{*}{ FY } & \multirow[b]{2}{*}{ Demands } & \multirow[b]{2}{*}{$\begin{array}{c}\text { Reactor } \\
\text { Years }\end{array}$} & \multicolumn{3}{|c|}{ Regression Curve Data Points } & \multicolumn{3}{|c|}{ Plot Trend Error Bar Points } \\
\hline & & & Mean & $\begin{array}{c}\text { Lower } \\
(5 \%)\end{array}$ & $\begin{array}{l}\text { Upper } \\
(95 \%)\end{array}$ & $\begin{array}{c}\text { Lower } \\
(5 \%)\end{array}$ & $\begin{array}{l}\text { Upper } \\
(95 \%)\end{array}$ & Mean \\
\hline 1998 & 38,468 & 103.0 & & & & $3.70 \mathrm{E}+02$ & $3.77 \mathrm{E}+02$ & $3.73 E+02$ \\
\hline 1999 & 41,230 & 103.0 & & & & $3.97 E+02$ & $4.04 \mathrm{E}+02$ & $4.00 \mathrm{E}+02$ \\
\hline 2000 & 41,357 & 103.3 & & & & $3.97 E+02$ & $4.04 \mathrm{E}+02$ & $4.00 \mathrm{E}+02$ \\
\hline 2001 & 41,400 & 103.0 & & & & $3.99 \mathrm{E}+02$ & $4.05 E+02$ & $4.02 E+02$ \\
\hline 2002 & 42,033 & 103.0 & $3.91 \mathrm{E}+02$ & $3.79 \mathrm{E}+02$ & $4.03 E+02$ & $4.05 E+02$ & 4.11E+02 & $4.08 \mathrm{E}+02$ \\
\hline 2003 & 42,440 & 103.0 & $3.87 \mathrm{E}+02$ & $3.77 \mathrm{E}+02$ & $3.98 \mathrm{E}+02$ & 4.09E+02 & 4.15E+02 & $4.12 \mathrm{E}+02$ \\
\hline 2004 & 41,435 & 103.3 & $3.84 \mathrm{E}+02$ & $3.74 \mathrm{E}+02$ & $3.94 E+02$ & $3.98 \mathrm{E}+02$ & $4.04 \mathrm{E}+02$ & $4.01 \mathrm{E}+02$ \\
\hline 2005 & 40,817 & 103.0 & $3.80 \mathrm{E}+02$ & $3.70 \mathrm{E}+02$ & $3.90 E+02$ & $3.93 E+02$ & $4.00 \mathrm{E}+02$ & $3.96 \mathrm{E}+02$ \\
\hline 2006 & 37,269 & 103.0 & $3.76 \mathrm{E}+02$ & $3.66 \mathrm{E}+02$ & $3.87 E+02$ & $3.59 \mathrm{E}+02$ & $3.65 E+02$ & $3.62 E+02$ \\
\hline 2007 & 37,400 & 103.4 & $3.73 E+02$ & $3.61 \mathrm{E}+02$ & $3.85 E+02$ & $3.59 \mathrm{E}+02$ & $3.65 \mathrm{E}+02$ & $3.62 \mathrm{E}+02$ \\
\hline 2008 & 37,664 & 104.3 & $3.69 \mathrm{E}+02$ & $3.56 \mathrm{E}+02$ & $3.82 E+02$ & $3.58 \mathrm{E}+02$ & $3.64 \mathrm{E}+02$ & $3.61 \mathrm{E}+02$ \\
\hline 2009 & 37,120 & 104.0 & $3.65 \mathrm{E}+02$ & $3.51 \mathrm{E}+02$ & $3.80 E+02$ & $3.54 \mathrm{E}+02$ & $3.60 \mathrm{E}+02$ & $3.57 E+02$ \\
\hline 2010 & 37,538 & 104.0 & $3.62 \mathrm{E}+02$ & $3.46 \mathrm{E}+02$ & $3.79 E+02$ & $3.58 \mathrm{E}+02$ & $3.64 \mathrm{E}+02$ & $3.61 \mathrm{E}+02$ \\
\hline 2011 & 37,116 & 104.0 & $3.58 \mathrm{E}+02$ & $3.41 \mathrm{E}+02$ & $3.77 E+02$ & $3.54 \mathrm{E}+02$ & $3.60 E+02$ & $3.57 \mathrm{E}+02$ \\
\hline Total & 553,286 & $1,447.2$ & & & & & & \\
\hline
\end{tabular}


Table 17. Plot data for frequency (events per reactor year) of MOV operation demands with $>20$ demands/yr. Figure 8

\begin{tabular}{|c|c|c|c|c|c|c|c|c|}
\hline \multirow[b]{2}{*}{ FY } & \multirow[b]{2}{*}{ Demands } & \multirow[b]{2}{*}{$\begin{array}{c}\text { Reactor } \\
\text { Years }\end{array}$} & \multicolumn{3}{|c|}{ Regression Curve Data Points } & \multicolumn{3}{|c|}{ Plot Trend Error Bar Points } \\
\hline & & & Mean & $\begin{array}{l}\text { Lower } \\
(5 \%)\end{array}$ & $\begin{array}{l}\text { Upper } \\
(95 \%)\end{array}$ & $\begin{array}{l}\text { Lower } \\
(5 \%)\end{array}$ & $\begin{array}{l}\text { Upper } \\
(95 \%)\end{array}$ & Mean \\
\hline 1998 & 38,473 & 103.0 & & & & $3.70 E+02$ & $3.77 \mathrm{E}+02$ & $3.74 \mathrm{E}+02$ \\
\hline 1999 & 41,208 & 103.0 & & & & $3.97 E+02$ & $4.03 E+02$ & $4.00 E+02$ \\
\hline 2000 & 41,333 & 103.3 & & & & $3.97 E+02$ & $4.03 E+02$ & $4.00 \mathrm{E}+02$ \\
\hline 2001 & 41,376 & 103.0 & & & & $3.98 E+02$ & $4.05 E+02$ & $4.02 E+02$ \\
\hline 2002 & 42,028 & 103.0 & & & & $4.05 E+02$ & 4.11E+02 & $4.08 \mathrm{E}+02$ \\
\hline 2003 & 42,430 & 103.0 & $4.01 \mathrm{E}+02$ & $3.83 E+02$ & 4.19E+02 & $4.09 E+02$ & $4.15 \mathrm{E}+02$ & $4.12 E+02$ \\
\hline 2004 & 41,432 & 103.3 & $3.94 \mathrm{E}+02$ & $3.79 \mathrm{E}+02$ & $4.09 E+02$ & $3.98 E+02$ & $4.04 \mathrm{E}+02$ & $4.01 E+02$ \\
\hline 2005 & 40,845 & 103.0 & $3.87 \mathrm{E}+02$ & $3.75 \mathrm{E}+02$ & $4.00 \mathrm{E}+02$ & $3.93 E+02$ & $4.00 \mathrm{E}+02$ & $3.97 \mathrm{E}+02$ \\
\hline 2006 & 37,259 & 103.0 & $3.81 \mathrm{E}+02$ & $3.71 \mathrm{E}+02$ & $3.92 E+02$ & $3.59 \mathrm{E}+02$ & $3.65 \mathrm{E}+02$ & $3.62 E+02$ \\
\hline 2007 & 37,350 & 103.4 & $3.75 \mathrm{E}+02$ & $3.66 \mathrm{E}+02$ & $3.84 \mathrm{E}+02$ & $3.58 \mathrm{E}+02$ & $3.64 \mathrm{E}+02$ & $3.61 \mathrm{E}+02$ \\
\hline 2008 & 37,628 & 104.3 & $3.69 \mathrm{E}+02$ & $3.60 \mathrm{E}+02$ & $3.78 \mathrm{E}+02$ & $3.58 \mathrm{E}+02$ & $3.64 \mathrm{E}+02$ & $3.61 \mathrm{E}+02$ \\
\hline 2009 & 37,087 & 104.0 & $3.63 E+02$ & $3.52 E+02$ & $3.73 E+02$ & $3.54 \mathrm{E}+02$ & $3.60 \mathrm{E}+02$ & $3.57 E+02$ \\
\hline 2010 & 37,562 & 104.0 & $3.57 \mathrm{E}+02$ & $3.45 \mathrm{E}+02$ & $3.69 \mathrm{E}+02$ & $3.58 \mathrm{E}+02$ & $3.64 \mathrm{E}+02$ & $3.61 \mathrm{E}+02$ \\
\hline 2011 & 37,123 & 104.0 & $3.51 \mathrm{E}+02$ & $3.37 \mathrm{E}+02$ & $3.65 E+02$ & $3.54 \mathrm{E}+02$ & $3.60 \mathrm{E}+02$ & $3.57 E+02$ \\
\hline 2012 & 36,918 & 104.3 & $3.45 \mathrm{E}+02$ & $3.29 \mathrm{E}+02$ & $3.61 \mathrm{E}+02$ & $3.51 \mathrm{E}+02$ & $3.57 \mathrm{E}+02$ & $3.54 \mathrm{E}+02$ \\
\hline Total & 590,052 & $1,551.5$ & & & & & & \\
\hline
\end{tabular}

Table 18. Plot data for frequency (events per reactor year) of MOV FTOC events with $\leq 20$ demands/yr. Figure 9

\begin{tabular}{|c|c|c|c|c|c|c|c|c|}
\hline \multirow[b]{2}{*}{ FY } & \multirow[b]{2}{*}{ Failures } & \multirow[b]{2}{*}{$\begin{array}{l}\text { Reactor } \\
\text { Years }\end{array}$} & \multicolumn{3}{|c|}{ Regression Curve Data Points } & \multicolumn{3}{|c|}{ Plot Trend Error Bar Points } \\
\hline & & & Mean & $\begin{array}{l}\text { Lower } \\
(5 \%)\end{array}$ & $\begin{array}{l}\text { Upper } \\
(95 \%)\end{array}$ & $\begin{array}{l}\text { Lower } \\
(5 \%)\end{array}$ & $\begin{array}{l}\text { Upper } \\
(95 \%)\end{array}$ & Mean \\
\hline 1998 & 41 & 103.0 & & & & 3.01E-01 & 5.13E-01 & 3.96E-01 \\
\hline 1999 & 51 & 103.0 & & & & $3.85 \mathrm{E}-01$ & $6.20 \mathrm{E}-01$ & 4.91E-01 \\
\hline 2000 & 45 & 103.3 & & & & 3.33E-01 & 5.54E-01 & 4.33E-01 \\
\hline 2001 & 43 & 103.0 & & & & 3.17E-01 & 5.35E-01 & 4.15E-01 \\
\hline 2002 & 35 & 103.0 & & & & $2.51 \mathrm{E}-01$ & 4.48E-01 & 3.39E-01 \\
\hline 2003 & 33 & 103.0 & 3.29E-01 & 2.26E-01 & 4.79E-01 & 2.35E-01 & 4.27E-01 & 3.20E-01 \\
\hline 2004 & 24 & 103.3 & 3.15E-01 & 2.29E-01 & 4.32E-01 & $1.61 \mathrm{E}-01$ & $3.27 \mathrm{E}-01$ & 2.33E-01 \\
\hline 2005 & 34 & 103.0 & 3.01E-01 & 2.31E-01 & 3.93E-01 & 2.43E-01 & 4.37E-01 & 3.29E-01 \\
\hline 2006 & 37 & 103.0 & $2.88 \mathrm{E}-01$ & 2.29E-01 & $3.62 \mathrm{E}-01$ & 2.67E-01 & 4.70E-01 & 3.58E-01 \\
\hline 2007 & 40 & 103.4 & 2.75E-01 & 2.22E-01 & 3.40E-01 & 2.91E-01 & 5.01E-01 & 3.85E-01 \\
\hline 2008 & 18 & 104.3 & 2.63E-01 & 2.11E-01 & $3.28 \mathrm{E}-01$ & 1.13E-01 & $2.57 \mathrm{E}-01$ & 1.74E-01 \\
\hline 2009 & 36 & 104.0 & $2.51 \mathrm{E}-01$ & 1.95E-01 & 3.24E-01 & 2.57E-01 & 4.55E-01 & 3.45E-01 \\
\hline 2010 & 27 & 104.0 & $2.40 \mathrm{E}-01$ & 1.78E-01 & 3.24E-01 & 1.84E-01 & 3.57E-01 & 2.60E-01 \\
\hline 2011 & 21 & 104.0 & 2.30E-01 & 1.61E-01 & 3.28E-01 & 1.37E-01 & $2.91 \mathrm{E}-01$ & 2.03E-01 \\
\hline 2012 & 19 & 104.3 & $2.20 \mathrm{E}-01$ & 1.45E-01 & 3.34E-01 & $1.21 \mathrm{E}-01$ & 2.68E-01 & 1.84E-01 \\
\hline Total & 504 & $1,551.5$ & & & & & & \\
\hline
\end{tabular}


Table 19. Plot data for frequency (events per reactor year) of MOV FTOC events with $>20$ demands/yr. Figure 10

\begin{tabular}{|c|c|c|c|c|c|c|c|c|}
\hline \multirow[b]{2}{*}{ FY } & \multirow[b]{2}{*}{ Failures } & \multirow[b]{2}{*}{$\begin{array}{c}\text { Reactor } \\
\text { Years }\end{array}$} & \multicolumn{3}{|c|}{ Regression Curve Data Points } & \multicolumn{3}{|c|}{ Plot Trend Error Bar Points } \\
\hline & & & Mean & $\begin{array}{c}\text { Lower } \\
(5 \%)\end{array}$ & $\begin{array}{l}\text { Upper } \\
(95 \%)\end{array}$ & $\begin{array}{c}\text { Lower } \\
(5 \%)\end{array}$ & $\begin{array}{l}\text { Upper } \\
(95 \%)\end{array}$ & Mean \\
\hline 1998 & 11 & 97.0 & & & & 6.41E-02 & $1.84 \mathrm{E}-01$ & 1.13E-01 \\
\hline 1999 & 14 & 97.0 & & & & 8.67E-02 & 2.20E-01 & $1.42 \mathrm{E}-01$ \\
\hline 2000 & 11 & 97.3 & & & & 6.39E-02 & $1.84 \mathrm{E}-01$ & 1.12E-01 \\
\hline 2001 & 16 & 97.0 & & & & $1.02 E-01$ & 2.44E-01 & 1.62E-01 \\
\hline 2002 & 13 & 97.0 & & & & 7.90E-02 & 2.08E-01 & $1.32 \mathrm{E}-01$ \\
\hline 2003 & 15 & 97.0 & 1.43E-01 & 8.39E-02 & 2.42E-01 & $9.44 \mathrm{E}-02$ & 2.32E-01 & $1.52 \mathrm{E}-01$ \\
\hline 2004 & 14 & 97.3 & $1.28 \mathrm{E}-01$ & 8.18E-02 & 1.99E-01 & 8.64E-02 & 2.20E-01 & $1.42 \mathrm{E}-01$ \\
\hline 2005 & 10 & 97.0 & 1.14E-01 & 7.86E-02 & $1.66 \mathrm{E}-01$ & 5.67E-02 & $1.72 \mathrm{E}-01$ & 1.03E-01 \\
\hline 2006 & 10 & 97.0 & $1.02 \mathrm{E}-01$ & 7.36E-02 & 1.43E-01 & 5.67E-02 & $1.72 \mathrm{E}-01$ & $1.03 \mathrm{E}-01$ \\
\hline 2007 & 9 & 97.4 & 9.17E-02 & $6.65 E-02$ & 1.27E-01 & 4.93E-02 & 1.59E-01 & 9.27E-02 \\
\hline 2008 & 10 & 98.3 & 8.22E-02 & 5.78E-02 & 1.17E-01 & 5.60E-02 & 1.70E-01 & $1.02 \mathrm{E}-01$ \\
\hline 2009 & 5 & 98.0 & 7.36E-02 & 4.87E-02 & 1.11E-01 & 2.22E-02 & $1.08 \mathrm{E}-01$ & 5.33E-02 \\
\hline 2010 & 2 & 98.0 & 6.59E-02 & 4.03E-02 & 1.08E-01 & 5.55E-03 & 6.82E-02 & $2.42 \mathrm{E}-02$ \\
\hline 2011 & 11 & 98.0 & 5.90E-02 & 3.29E-02 & 1.06E-01 & 6.34E-02 & $1.82 \mathrm{E}-01$ & 1.11E-01 \\
\hline 2012 & 8 & 98.3 & 5.29E-02 & 2.67E-02 & 1.05E-01 & 4.19E-02 & 1.46E-01 & $8.22 \mathrm{E}-02$ \\
\hline Total & 159 & $1,461.4$ & & & & & & \\
\hline
\end{tabular}


Table 20. Plot data for frequency (events per reactor year) of MOV FTOP events with $\leq 20$ demands/yr. Figure 11

\begin{tabular}{|c|c|c|c|c|c|c|c|c|}
\hline \multirow[b]{2}{*}{ FY } & \multirow[b]{2}{*}{ Failures } & \multirow[b]{2}{*}{$\begin{array}{l}\text { Reactor } \\
\text { Years }\end{array}$} & \multicolumn{3}{|c|}{ Regression Curve Data Points } & \multicolumn{3}{|c|}{ Plot Trend Error Bar Points } \\
\hline & & & Mean & $\begin{array}{l}\text { Lower } \\
(5 \%)\end{array}$ & $\begin{array}{l}\text { Upper } \\
(95 \%)\end{array}$ & $\begin{array}{l}\text { Lower } \\
(5 \%)\end{array}$ & $\begin{array}{l}\text { Upper } \\
(95 \%)\end{array}$ & Mean \\
\hline 1998 & 2 & 103.0 & & & & $4.58 \mathrm{E}-03$ & $5.62 \mathrm{E}-02$ & $2.00 \mathrm{E}-02$ \\
\hline 1999 & 5 & 103.0 & & & & 1.83E-02 & 8.94E-02 & 4.40E-02 \\
\hline 2000 & 13 & 103.3 & & & & $6.44 \mathrm{E}-02$ & $1.70 \mathrm{E}-01$ & $1.08 \mathrm{E}-01$ \\
\hline 2001 & 3 & 103.0 & & & & 8.67E-03 & 6.76E-02 & 2.80E-02 \\
\hline 2002 & 4 & 103.0 & & & & 1.33E-02 & 7.87E-02 & 3.60E-02 \\
\hline 2003 & 3 & 103.0 & 2.43E-02 & 8.85E-03 & 6.67E-02 & 8.67E-03 & 6.76E-02 & $2.80 \mathrm{E}-02$ \\
\hline 2004 & 4 & 103.3 & $2.29 \mathrm{E}-02$ & $9.75 \mathrm{E}-03$ & 5.37E-02 & 1.33E-02 & 7.85E-02 & 3.59E-02 \\
\hline 2005 & 3 & 103.0 & 2.15E-02 & 1.05E-02 & 4.42E-02 & 8.67E-03 & $6.76 \mathrm{E}-02$ & 2.80E-02 \\
\hline 2006 & 1 & 103.0 & 2.03E-02 & 1.09E-02 & 3.76E-02 & 1.41E-03 & 4.43E-02 & 1.20E-02 \\
\hline 2007 & 2 & 103.4 & 1.91E-02 & 1.08E-02 & 3.38E-02 & 4.57E-03 & 5.61E-02 & 1.99E-02 \\
\hline 2008 & 1 & 104.3 & 1.80E-02 & 9.98E-03 & 3.24E-02 & 1.39E-03 & 4.38E-02 & 1.19E-02 \\
\hline 2009 & 0 & 104.0 & 1.69E-02 & 8.68E-03 & 3.31E-02 & 1.56E-05 & 3.10E-02 & 3.97E-03 \\
\hline 2010 & 4 & 104.0 & 1.60E-02 & 7.23E-03 & 3.52E-02 & 1.32E-02 & 7.80E-02 & 3.57E-02 \\
\hline 2011 & 1 & 104.0 & 1.50E-02 & 5.87E-03 & 3.84E-02 & 1.40E-03 & 4.39E-02 & 1.19E-02 \\
\hline 2012 & 4 & 104.3 & $1.41 \mathrm{E}-02$ & 4.69E-03 & 4.27E-02 & 1.32E-02 & 7.79E-02 & 3.56E-02 \\
\hline Total & 50 & $1,551.5$ & & & & & & \\
\hline
\end{tabular}

Table 21. Plot data for frequency (events per reactor year) of MOV FTOP events with $>20$ demands/yr. Figure 12

\begin{tabular}{|c|c|c|c|c|c|c|c|c|}
\hline \multirow[b]{2}{*}{ FY } & \multirow[b]{2}{*}{ Failures } & \multirow[b]{2}{*}{$\begin{array}{c}\text { Reactor } \\
\text { Years }\end{array}$} & \multicolumn{3}{|c|}{ Regression Curve Data Points } & \multicolumn{3}{|c|}{ Plot Trend Error Bar Points } \\
\hline & & & Mean & $\begin{array}{l}\text { Lower } \\
(5 \%)\end{array}$ & $\begin{array}{l}\text { Upper } \\
(95 \%)\end{array}$ & $\begin{array}{l}\text { Lower } \\
(5 \%)\end{array}$ & $\begin{array}{l}\text { Upper } \\
(95 \%)\end{array}$ & Mean \\
\hline 1998 & 0 & 97.0 & & & & 1.53E-05 & 3.04E-02 & 3.89E-03 \\
\hline 1999 & 4 & 97.0 & & & & 1.29E-02 & 7.66E-02 & $3.50 \mathrm{E}-02$ \\
\hline 2000 & 1 & 97.3 & & & & 1.37E-03 & 4.30E-02 & 1.17E-02 \\
\hline 2001 & 0 & 97.0 & & & & $1.53 \mathrm{E}-05$ & 3.04E-02 & 3.89E-03 \\
\hline 2002 & 1 & 97.0 & & & & 1.37E-03 & 4.31E-02 & 1.17E-02 \\
\hline 2003 & 1 & 97.0 & $1.24 \mathrm{E}-02$ & 3.35E-03 & 4.61E-02 & 1.37E-03 & 4.31E-02 & 1.17E-02 \\
\hline 2004 & 3 & 97.3 & $1.23 \mathrm{E}-02$ & 4.03E-03 & 3.72E-02 & 8.42E-03 & 6.57E-02 & 2.72E-02 \\
\hline 2005 & 1 & 97.0 & $1.21 \mathrm{E}-02$ & $4.74 \mathrm{E}-03$ & 3.07E-02 & $1.37 \mathrm{E}-03$ & 4.31E-02 & 1.17E-02 \\
\hline 2006 & 0 & 97.0 & 1.19E-02 & 5.36E-03 & 2.64E-02 & $1.53 \mathrm{E}-05$ & 3.04E-02 & 3.89E-03 \\
\hline 2007 & 2 & 97.4 & 1.17E-02 & $5.71 \mathrm{E}-03$ & 2.40E-02 & 4.45E-03 & 5.46E-02 & 1.94E-02 \\
\hline 2008 & 0 & 98.3 & 1.15E-02 & 5.60E-03 & 2.38E-02 & $1.52 \mathrm{E}-05$ & 3.01E-02 & 3.85E-03 \\
\hline 2009 & 1 & 98.0 & 1.14E-02 & $5.08 \mathrm{E}-03$ & 2.54E-02 & 1.36E-03 & 4.27E-02 & 1.16E-02 \\
\hline 2010 & 3 & 98.0 & 1.12E-02 & 4.34E-03 & 2.89E-02 & 8.37E-03 & 6.53E-02 & $2.70 \mathrm{E}-02$ \\
\hline 2011 & 4 & 98.0 & 1.10E-02 & $3.57 \mathrm{E}-03$ & 3.41E-02 & 1.28E-02 & 7.60E-02 & $3.48 \mathrm{E}-02$ \\
\hline 2012 & 0 & 98.3 & 1.09E-02 & 2.88E-03 & 4.10E-02 & 1.52E-05 & 3.01E-02 & 3.85E-03 \\
\hline Total & 21 & $1,461.4$ & & & & & & \\
\hline
\end{tabular}


Table 22. Plot data for frequency (events per reactor year) of MOV SO events $\leq 20$ demands/yr. Figure 13

\begin{tabular}{|c|c|c|c|c|c|c|c|c|}
\hline \multirow[b]{2}{*}{ FY } & \multirow[b]{2}{*}{ Failures } & \multirow[b]{2}{*}{$\begin{array}{l}\text { Reactor } \\
\text { Years }\end{array}$} & \multicolumn{3}{|c|}{ Regression Curve Data Points } & \multicolumn{3}{|c|}{ Plot Trend Error Bar Points } \\
\hline & & & Mean & $\begin{array}{l}\text { Lower } \\
(5 \%)\end{array}$ & $\begin{array}{l}\text { Upper } \\
(95 \%)\end{array}$ & $\begin{array}{l}\text { Lower } \\
(5 \%)\end{array}$ & $\begin{array}{l}\text { Upper } \\
(95 \%)\end{array}$ & Mean \\
\hline 1998 & 6 & 103.0 & & & & $2.22 \mathrm{E}-02$ & $9.42 \mathrm{E}-02$ & 4.90E-02 \\
\hline 1999 & 1 & 103.0 & & & & 1.33E-03 & 4.17E-02 & 1.13E-02 \\
\hline 2000 & 6 & 103.3 & & & & 2.22E-02 & $9.40 \mathrm{E}-02$ & 4.89E-02 \\
\hline 2001 & 3 & 103.0 & & & & 8.17E-03 & 6.38E-02 & 2.64E-02 \\
\hline 2002 & 3 & 103.0 & & & & 8.17E-03 & 6.38E-02 & 2.64E-02 \\
\hline 2003 & 3 & 103.0 & 1.39E-02 & 3.08E-03 & $6.23 E-02$ & 8.17E-03 & 6.38E-02 & 2.64E-02 \\
\hline 2004 & 0 & 103.3 & $1.31 \mathrm{E}-02$ & 3.67E-03 & 4.68E-02 & $1.48 \mathrm{E}-05$ & 2.94E-02 & 3.76E-03 \\
\hline 2005 & 0 & 103.0 & $1.24 \mathrm{E}-02$ & 4.26E-03 & $3.62 E-02$ & 1.48E-05 & 2.95E-02 & 3.77E-03 \\
\hline 2006 & 1 & 103.0 & 1.17E-02 & 4.70E-03 & 2.94E-02 & 1.33E-03 & 4.17E-02 & 1.13E-02 \\
\hline 2007 & 6 & 103.4 & 1.11E-02 & 4.82E-03 & 2.57E-02 & 2.22E-02 & $9.40 \mathrm{E}-02$ & 4.89E-02 \\
\hline 2008 & 3 & 104.3 & 1.05E-02 & 4.48E-03 & 2.47E-02 & 8.09E-03 & 6.32E-02 & 2.61E-02 \\
\hline 2009 & 3 & 104.0 & 9.96E-03 & 3.81E-03 & 2.61E-02 & 8.11E-03 & 6.33E-02 & $2.62 \mathrm{E}-02$ \\
\hline 2010 & 1 & 104.0 & 9.43E-03 & 3.03E-03 & 2.93E-02 & 1.32E-03 & 4.14E-02 & 1.12E-02 \\
\hline 2011 & 0 & 104.0 & 8.93E-03 & 2.32E-03 & 3.44E-02 & 1.47E-05 & 2.92E-02 & $3.74 \mathrm{E}-03$ \\
\hline 2012 & 0 & 104.3 & 8.45E-03 & 1.73E-03 & 4.13E-02 & 1.47E-05 & 2.92E-02 & $3.73 \mathrm{E}-03$ \\
\hline Total & 36 & $1,551.5$ & & & & & & \\
\hline
\end{tabular}

Table 23. Plot data for frequency (events per reactor year) of MOV SO events $>20$ demands/yr. Figure 14

\begin{tabular}{ccccccccc} 
& & & \multicolumn{2}{c}{ Regression Curve Data Points } & \multicolumn{2}{c}{ Plot Trend Error Bar Points } \\
\cline { 6 - 9 } FY & Failures & $\begin{array}{c}\text { Reactor } \\
\text { Years }\end{array}$ & Mean & $\begin{array}{c}\text { Lower } \\
\mathbf{( 5 \% )}\end{array}$ & $\begin{array}{c}\text { Upper } \\
\mathbf{( 9 5 \% )}\end{array}$ & $\begin{array}{c}\text { Lower } \\
\mathbf{( 5 \% )}\end{array}$ & $\begin{array}{c}\text { Upper } \\
\mathbf{( 9 5 \% )}\end{array}$ & Mean \\
\hline 1998 & 0 & 97.0 & & & & $1.14 \mathrm{E}-05$ & $2.27 \mathrm{E}-02$ & $2.91 \mathrm{E}-03$ \\
\hline 1999 & 1 & 97.0 & & & & $1.02 \mathrm{E}-03$ & $3.22 \mathrm{E}-02$ & $8.72 \mathrm{E}-03$ \\
\hline 2000 & 0 & 97.3 & & & & $1.14 \mathrm{E}-05$ & $2.27 \mathrm{E}-02$ & $2.90 \mathrm{E}-03$ \\
\hline 2001 & 0 & 97.0 & & & & $1.14 \mathrm{E}-05$ & $2.27 \mathrm{E}-02$ & $2.91 \mathrm{E}-03$ \\
\hline 2002 & 0 & 97.0 & & & & $1.14 \mathrm{E}-05$ & $2.27 \mathrm{E}-02$ & $2.91 \mathrm{E}-03$ \\
\hline 2003 & 1 & 97.0 & $3.20 \mathrm{E}-03$ & $1.37 \mathrm{E}-03$ & $7.50 \mathrm{E}-03$ & $1.02 \mathrm{E}-03$ & $3.22 \mathrm{E}-02$ & $8.72 \mathrm{E}-03$ \\
\hline 2004 & 0 & 97.3 & $3.58 \mathrm{E}-03$ & $1.74 \mathrm{E}-03$ & $7.38 \mathrm{E}-03$ & $1.14 \mathrm{E}-05$ & $2.27 \mathrm{E}-02$ & $2.90 \mathrm{E}-03$ \\
\hline 2005 & 0 & 97.0 & $4.01 \mathrm{E}-03$ & $2.18 \mathrm{E}-03$ & $7.37 \mathrm{E}-03$ & $1.14 \mathrm{E}-05$ & $2.27 \mathrm{E}-02$ & $2.91 \mathrm{E}-03$ \\
\hline 2006 & 0 & 97.0 & $4.49 \mathrm{E}-03$ & $2.67 \mathrm{E}-03$ & $7.54 \mathrm{E}-03$ & $1.14 \mathrm{E}-05$ & $2.27 \mathrm{E}-02$ & $2.91 \mathrm{E}-03$ \\
\hline 2007 & 0 & 97.4 & $5.02 \mathrm{E}-03$ & $3.15 \mathrm{E}-03$ & $8.01 \mathrm{E}-03$ & $1.14 \mathrm{E}-05$ & $2.27 \mathrm{E}-02$ & $2.90 \mathrm{E}-03$ \\
\hline 2008 & 0 & 98.3 & $5.62 \mathrm{E}-03$ & $3.53 \mathrm{E}-03$ & $8.96 \mathrm{E}-03$ & $1.13 \mathrm{E}-05$ & $2.25 \mathrm{E}-02$ & $2.88 \mathrm{E}-03$ \\
\hline 2009 & 1 & 98.0 & $6.29 \mathrm{E}-03$ & $3.75 \mathrm{E}-03$ & $1.05 \mathrm{E}-02$ & $1.02 \mathrm{E}-03$ & $3.20 \mathrm{E}-02$ & $8.67 \mathrm{E}-03$ \\
\hline 2010 & 2 & 98.0 & $7.04 \mathrm{E}-03$ & $3.84 \mathrm{E}-03$ & $1.29 \mathrm{E}-02$ & $3.31 \mathrm{E}-03$ & $4.06 \mathrm{E}-02$ & $1.44 \mathrm{E}-02$ \\
\hline 2011 & 1 & 98.0 & $7.88 \mathrm{E}-03$ & $3.84 \mathrm{E}-03$ & $1.62 \mathrm{E}-02$ & $1.02 \mathrm{E}-03$ & $3.20 \mathrm{E}-02$ & $8.67 \mathrm{E}-03$ \\
\hline 2012 & 1 & 98.3 & $8.82 \mathrm{E}-03$ & $3.78 \mathrm{E}-03$ & $2.06 \mathrm{E}-02$ & $1.01 \mathrm{E}-03$ & $3.19 \mathrm{E}-02$ & $8.65 \mathrm{E}-03$ \\
\hline Total & 7 & $1,461.4$ & & & & & & \\
\hline
\end{tabular}




\section{REFERENCES}

1. Nuclear Regulatory Commission, Component Reliability Data Sheets Update 2010, January 2012, http://nrcoe.inl.gov/resultsdb/publicdocs/AvgPerf/ComponentReliabilityDataSheets2010.pdf

2. S.A. Eide et al., Industry-Average Performance for Components and Initiating Events at U.S. Commercial Nuclear Power Plants, NUREG/CR-6928, Nuclear Regulatory Commission, February 2007. 
